\title{
А.В. Манойло
}

\section{О ПРОТИВОДЕЙСТВИИ ЦВЕТНЫМ РЕВОЛЮЦИЯМ}

\begin{abstract}
Аннотация: Настоящая статья посвящена анализу проблем, связанных с демонтажем политических режимов в современных государствах (как авторитарного, так и демократического типа) и ролью в этом процессе технологий цветных революций, включая возможности противодействия их деструктивному влиянию на мировой политический процесс. В этом плане имеет большое значение систематизация и уточнение терминологии, связанной с цветными революциями, что вносит ясность и четкость в предмет исследования и позволяет понять природу цветных революций, а также выбрать методы, позволяющие с ними бороться. Проблемы демонтажа политических режимов и связанная с ними проблематика цветных революций в современных условиях приобретают чрезвычайную остроту и актуальность. Связано это не только с тем, что события в Украине при детальном рассмотрении в точности повторяют сценарий цветных революций в Северной Африке и на Ближнем Востоке, получивших название "Арабской Весны», в частности - революции в Египте, что указывает на неслучайность данных событий. Причина в том, что на смену традиционным, привычным для мирового сообщества инструментам демонтажа приходит новое поколение более тонких инструментов, сочетающих силовые методы воздействия с технологиями манипулятивного управления массовым сознанием и массовым поведением широких масс гражданского населения.
\end{abstract}

Ключевые слова: международные отношения, внешняя политика, цветные революции, Арабская Весна, Крым, дипломатия, государство, политический режим, конфликт, безопасность.

\section{I. ЦВЕТНЫЕ РЕВОЛЮЦИИ (термины и определения)}

«Цветные революции» в классическом виде и любые их разновидности - это технологии информационно-психологического управления международными конфликтами, предполагающие, в том числе, их искусственную инициацию. Именно в состояние таких этнополитических конфликтов погрузились общества в раннее стабильных и политически предсказуемых государствах Ближнего Востока и Северной Африки после внешней инициации технологий «управляемого хаоса».

В более узком смысле цветные революции это технологии осуществления государственных переворотов и внешнего управления политической ситуацией в стране в условиях политической нестабильности, в которых давление на власть осуществляется в форме политического шантажа с использованием в качестве инструмента шантажа молодежного протестного движения.

Современные цветные революции отличаются высокой степенью технологичности и почти театральным уровнем драматургии, который западные политологи старательно пытаются выдать за самопроизвольное и стихийное проявление воли народа, внезапно решившего вернуть себе право управлять собственной страной. Несмотря на существенные различия государств, в которых они вспыхивают, между собой (в геополитическом, со- циальном, экономическом плане и международном положении), все они укладываются в одну и ту же организационную схему, предполагающую организацию по шаблону молодежного протестного движения, преобразования его в политическую толпу и использование этой силы против действующей власти в качестве инструмента политического шантажа.

В основе технологического сценария цветной революции лежит англосаксонская (североамериканская) идеология демократизации, предполагающая экспорт демократии, демократических институтов и ценностей в сопредельные страны. При этом все государства должны строить демократическое общество по образцу США.Технологии цветных революций на практике умеют применять только их авторы и разработчики - англосаксы. В любой стране, где начала разворачиваться цветная революция, следует искать северомериканский след.

Все цветные революции построены по одной и той же схеме, или технологической цепочке - это невозможно не заметить. Это прямо указывает на то, что цветные революции в принципе не могут быть реализацией объективных надежд и стремлений большинства населения. Достаточно взглянуть на национально-освободительные движения и войны в странах Азии, Африки и Латинской Америки, закончившиеся сменой власти: все они пришли к власти разными путями, но всегда исключительно благодаря поддержке населения. Наивно полагать, что 
цветные революции - это стихийное проявление, всплеск народного гнева, «народный бунт», проявление народной воли: все это не что иное как красивая легенда, сказка, образ конфликта, за которой скрывается банальный государственный переворот, организованный из-за рубежа. Даже западные СМИ сегодня отмечают, что технологии проведения операций по экспорту демократии через акции гражданского неповиновения настолько отточена, что их методы превратились в руководство по смене политических режимов.

Цветные революции часто называют технологиями или инструментами «мягкой силы», понимаемой в том ракурсе, который дал для этого термина Дж. Най. Этот подход, основанный на принципе аналогии (внешне цветные революции - это несиловые технологии смены политических режимов), не совсем точен и часто вводит в заблуждение, заставляя считать цветные революции более мягкой и поэтому более прогрессивной и менее социально опасной формой воздействия на авторитарные режимы. Тем самым разворачивается кампания по пропаганде цветных революций в пику любым формам собственно вооруженных переворотов. На наш взгляд, трудно определить, что на самом деле является более опасным явлением для международной безопасности в целом: цветные революции или локальные вооруженные конфликты, и современный Ближний Восток, погруженный цветными революциями в «управляемый» хаос, является полным тому подтверждением. Все же, представляется довольно очевидным, что современные цветные революции по своей природе - это не форма проявления «мягкой силы». Цветные революции - это не что иное, как организационная форма осуществления государственного шантажа (то есть шантажа, объектом которого является независимое и суверенное государство), маскирующегося под легендой и лозунгами национальной революции.

У каждой цветной революции есть свои признаки, которые выдают в ней технологию. Вопервых, это особый внешнеполитический почерк англосаксов, их отличительный стиль работы. Вовторых, это строгое соответствие плана любой революции базовому шаблону (или сыенарию) - все цветные революции развиваются по одному и тому же сценарию, использующего одну шаблонную схему. В-третьих, это то, каким образом организуется и как используется молодежное протестное движение, которым управляют с помощью технологий рефлексивного управления (которые также являются американским изобретением). В-четвертых, есть определенные повторяющиеся особенности в подборе и выдвижении революционных лидеров. В-пятых, в некоторых цветных революциях начисто отсутствует революционная идеология, что позволяет распознать в них подделку. Связан это с тем, что американцы- авторы цветных революций - не всегда понимают менталитет и психологию народа, которым они хотят принести «ценности истинной демократии», и не могут предложить им идеологию, которая будет органично принята всеми слоями общества.

Модель, лежащая в основе цветной революции, одна: это создание протестного движения, превращение его в политическую толпу и направление ее агрессии на действующую власть с целью заставить ее добровольно уйти с государственных постов и отказаться от управления страной. Такое давление на власть всегда происходит в форме шантажа, выдвижения ультиматумов под угрозой массовых погромов и - реже - физических расправ с инакомыслящими. Если власть начинает сопротивляться, цветная революция переходит в фазу вооруженного мятежа. Иногда этот мятеж сопровождается вооруженной интервенцией со стороны западных стран, как это было в Ливии и, скорее всего, будет в Сирии.

Модель цветной революции состоит из пяти основных этапов, или фаз:

1. Любая цветная революция начинается с формирования в стране организованного протестного движения - основной движущей силы будущей цветной революции.

На первоначальном этапе, до открытого выступления, протестное движение формируется в виде сети, состоящей из конспиративных ячеек, каждая из которых состоит из лидера и трех-четырех состоящих у него на связи активистов. Такие сети объединяют тысячи активистов, составляющих ядро будущего протестного движения. Многие из них перед тем, как стать лидерами ячеек, проходят обучение в специальных центрах, специализирующихся на вопросах содействия демократизации.

Рекрутируют активистов из молодежной среды, чрезвычайно подвижной и легко увлекаемой различными яркими призывами и лозунгами.

Сетевой принцип организации протестного движения напоминает принцип организации глобальных террористических сетей - по сути, это одна организационная технология.

2. Из подполья эта сеть выходит на улицы крупных городов одновременно и по условному сигналу, который носит название инцидента. Та- 


\section{Международные отношения / International Relations}

ким инцидентом может стать любое событие, шокирующее общество и получившее мощный общественный резонанс. Как правило, его инициируют специально.

В революциях в Сербии (бульдозерная революция 2000), в Украине (2004) и в Грузии (2004) таким инцидентом стали результаты выборов, которые были объявлены сфальсифицированными. Революция в Тунисе (2010) - стране с авторитарным режимом - началась с самосожжения торговца на одной из центральных площадей столицы: событие, само по себе, ничтожное в масштабах страны.

Очень важно, чтобы инцидент привлек внимание всего общества и стал предметом широкого обсуждения, интерпретации, нарастания всеобщего возбуждения и инициирования стихийных форм массового поведения.

3. После того, как инцидент произошел, протестная сеть выходит из подполья на улицы, где группы активистов из ячеек становятся катализатором стихийных массовых процессов, вовлекающих в этот процесс все большие слои населения.

Включаются механизмы конфликтной мобилизации, одним из которых являются «твиттерные революции» - вовлечение через социальные сети.

Ячейки начинают быстро обрастать гражданами, вовлекаемыми в стихийное протестное движение, принять участие в котором их толкает в основном страх за свое будущее. Общая тревожность настроений ведет к тому, что сознание людей переходит в так называемое пограничное состояние и становится подверженным массовым паническим реакциям, всеобщей истерии, часто проявляющихся на уровне рефлексов и инстинктов. С этого момента остается только один шаг от превращения протестных масс из сообщества протестующих в толпу.

4. Следующий шаг в схеме цветной революции - формирование политической толпы. Для этого выбирается достаточно большая площадь (майдан), где могли бы разместиться значительные массы народа.

Активисты ведут свой протестный электорат на такой майдан, где в ходе многочасового митинга происходит полное слияние участников в единую массу, известную в психологии как толпа. Происходит полное эмоциональное слияние отдельных личностей с толпой, в которой для идентификации свой-чужой начинает использоваться яркая «революционная» опознавательная символика.

В этих условиях на толпу воздействуют с помощью технологий воздействия ан подсознание, внедряя новые ценности и императивы, перепро- граммируя человека. Именно такие технологии применяются в протестантских тоталитарных сектах.

Создаются условия для поддержания устойчивого существования и функционирования толпы - материальное обеспечение, палатки, горячее питание, одежда, деньги активистам, средства нападения (арматура, ...) и т.д. Действует хорошо организованная «служба тыла».

5. От имени толпы к власти выдвигаются ультимативные требования, под угрозой массовых беспорядков и - реже - физического уничтожения. В том случае, если власть не выдерживает этого напора, стихия ее сметает. Если власть принимает вызов и выражает готовность сопротивляться, толпа становится основным таранным фактором удара, который наносят по власти авторы цветной революции. В дальнейшем такая революция неизбежно перерастает в мятеж, а в некоторых случаях в гражданскую войну, сопровождающуюся военной интервенцией.

Эволюция организационных схем и шаблонов цветных революций довольно хорошо прослеживается на примере революций Арабской весны. Так, в революциях Арабской весны есть свои особенности, отличающие их структурно и технологически от своих предшественников - цветных революций в Центральной Азии, Украине, Грузии и даже от т.н. «зеленой революции» в Иране 2009 года: к классической схеме реализации цветной революции (то есть государственного переворота) здесь добавлены механизмы обратной связи (итерационный механизм, хорошо известный математикам) и «управляемого хаоса», позволяющие управлять политической нестабильностью не только в рамках отдельно взятой, сравнительно небольшой страны (такой как Украина или Грузия), но и в масштабах целого региона (Ближнего Востока, Северной Африки, Центральной Азии и т.д.).

Механизм обратной связи - это специальный механизм коррекции, позволяющий в режиме реального времени выявлять и оперативно устранять недочеты в реализации схем цветных революций, модифицируя их под конкретные условия конкретной социокультурной среды. Именно такой механизм был впервые отработан в революциях Арабской весны, в которых государственные перевороты в странах, ставших жертвами волны «принудительной демократизации», осуществлялись не одновременно, а последовательно, по цепочке; причем в каждой последующей схеме реализации цветной революции учитывались ошибки, допущенные при реализации предыдущей схемы. 
Внедрение в технологические схемы цветных революций механизмов обратной связи, основанных на итерационных схемах, - это прямой результат их эволюционного развития, позволяющий погружать в революционные процессы уже не отдельные страны. а целые регионы.

Механизм «управляемого хаоса» - это еще один эволюционный прорыв в технологиях цветных революций, который позволяет применять «демократические схемы и шаблоны», разработанные изначально для общества западного (индивидуалистического) типа, в условиях традиционных восточных обществ, в своем исходном виде невосприимчивых к пропаганде демократических и либеральных ценностей. Для того чтобы западные, англосаксонские, технологии цветных революций заработали в такого рода социально-культурной среде, необходимо предварительно разрушить традиционную структуру общественного уклада, что и делают (и весьма успешно) технологии «управляемого хаоса». Основная цель применения этих технологий - подготовить традиционное общество к применению технологий управления массовым политическим сознанием и массовым политическим поведением, что достигается с помощью его «атомизации», разрыва связей между отдельными личностями и общиной, внедрения в сознание граждан суррогатного индивидуализма западного типа. В революциях «Арабской весны» есть и свои особенности, отличающие их структурно и технологически от своих предшественников - цветных революций в Центральной Азии, Украине, Грузии и даже от т.н. «зеленой революции» в Иране 2009 года: к классической схеме реализации цветной революции (то есть государственного переворота) здесь добавлены механизмы обратной связи (итерационный механизм, хорошо известный математикам) и «управляемого хаоса», позволяющие управлять политической нестабильностью не только в рамках отдельно взятой, сравнительно небольшой страны (такой как Украина или Грузия), но и в масштабах целого региона (Ближнего Востока, Северной Африки, Центральной Азии и т.д.).

Механизм обратной связи - это специальный механизм коррекции, позволяющий в режиме реального времени выявлять и оперативно устранять недочеты в реализации схем цветных революций, модифицируя их под конкретные условия конкретной социокультурной среды. Именно такой механизм был впервые отработан в революциях «Арабской весны», в которых государственные перевороты в странах, ставших жертвами волны «принудительной демократизации», осуществлялись не одновременно, а последовательно, по цепочке; причем в каждой последующей схеме реализации цветной революции учитывались ошибки, допущенные при реализации предыдущей схемы. Внедрение в технологические схемы цветных революций механизмов обратной связи, основанных на итерационных схемах, - это прямой результат их эволюционного развития, позволяющий погружать в революционные процессы уже не отдельные страны. а целые регионы.

Механизм «управляемого хаоса» - это еще один эволюционный прорыв в технологиях цветных революций, который позволяет применять «демократические схемы и шаблоны», разработанные изначально для общества западного (индивидуалистического) типа, в условиях традиционных восточных обществ, в своем исходном виде невосприимчивых к пропаганде демократических и либеральных ценностей. Для того чтобы западные, англосаксонские, технологии цветных революций заработали в такого рода социально-культурной среде, необходимо предварительно разрушить традиционную структуру общественного уклада, что и делают (и весьма успешно) технологии «управляемого хаоса». Основная цель применения этих технологий - подготовить традиционное общество к применению технологий управления массовым политическим сознанием и массовым политическим поведением, что достигается с помощью его «атомизации», разрыва связей между отдельными личностями и общиной, внедрения в сознание граждан суррогатного индивидуализма западного типа.

На волне цветных революций Арабской весны, осуществляемых по американскому сценарию, поднимают голову экстремистские исламские организации, которые считают, что их час пришел: американцы и их союзники по НАТО, устраняя неугодные светские режимы, тем самым расчищают площадку для любых сил, способных взять власть в свои руки (наиболее яркий пример - Египет под властью «Братьев-мусульман»). Эти силы в регионе представлены в основном радикальными исламскими организациями, которые сегодня идут на острие удара англосаксонской демократии. При этом из изгоев, всеми преследуемых и осуждаемых, они превращаются практически в легитимную политическую силу, с которой уже можно вести переговоры, вступать в союзы и иметь партнерские отношения. Более того, в эти организации их западными партнерами вливаются огромные ресур- 
сы, которые позволяют лидерам этих организаций говорить о собственном возрождении и связывать эти процессы с новым возрождением ислама.

В условиях, когда в радикальных исламистских организациях (как суннитских, так и шиитских), имеющих опыт участия в вооружённых конфликтах, появилась реальная потребность и у авторов революций Арабской весны, и у их противников, эти организации резко увеличивают интенсивность и выводят на новый качественный уровень свою информационно-пропагандистскую деятельность. В арсенале этой деятельности появляются новые идеологические установки, связывающие интересы радикальных исламистских сект с интересами глобального исламского возрождения, новые методы и технологии воздействия на массовое и индивидуальное сознание людей. И дело здесь не только в стремлении расширить собственную социальную базу, необходимую для вербовки боевиков, а в том, что сегодня идеологами экстремистов закладывается фундамент новой идеологии всемирного возрождения ислама, главными элементами которого становятся призывы к глобальной исламской революции, исламский ревизионизм и создание всемирного халифата. И все это сегодня происходит под крылом и почти отеческой опекой западных союзников, рассматривающих исламистов как полезный инструмент в той игре, которая разыгрывается сегодня на Ближнем Востоке. Вот почему информационно-пропагандистскую политику радикальных исламистских организаций необходимо тщательно исследовать и постоянно держать в поле зрения, поскольку именно она является основным индикатором, посылающим сигналы о новых угрозах международной безопасности и существующему миропорядку.

Революции Арабской Весны несут отсталому (по меркам западного мира) обществу, якобы томящемуся под гнетом полуфеодальных военных диктатур, ценности истинной демократии, свободы и народовластия, то есть - все лучшее, что может предложить западная либеральная цивилизация остальному миру ${ }^{1}$. Однако эти ценности в революциях «Арабской весны» несут народам на остриях своих штыков шейхи монархий Персидского залива, идущие в авангарде американских и НАТОвских экспедиционных корпусов, - саудовцы и катарцы, кото-

\footnotetext{
Hale H.E. Democracy or autocracy on the march? The colored revolutions as normal dynamics of patronal presidentialism. // Communist and Post-Communist Studies. 2006. Vol 39. №3. pp. 305-329.
}

рых даже при всех возможных допущениях весьма сложно назвать либералами и демократами.

Запад упорно продолжает называть государственные перевороты в арабских странах «революциями», но при этом замалчивает отсутствие в этих революциях подлинно революционной идеологии. Ведь революция тем и отличается от мятежа, что у нее есть свои идеалы и фанатично следующие им революционеры-идеалисты, есть своя революционная идеология, а у мятежников такой идеологии нет - она им не нужна, так как мятеж поднимают не ради идеи, а против кого-то конкретного.

Революционеры Арабской весны (эти «подснежники» пустыни) борются с реакционными режимами, стремясь смести приватизировавшие власть в своих интересах военные хунты вроде клана Асадов в Сирии или Каддафи в Ливии. При этом СМИ часто рисуют проправительственные силы в виде террористов и военных преступников, ведущих войну против собственного народа, обстреливающих из танков и вертолетов густонаселенные жилые кварталы, идущих ради сохранения собственной власти на любые преступления, вплоть до геноцида. При этом как то забывается, что основные кадры для свободных армий мятежников поставляют все те же террористические организации: в Свободной сирийской армии против Асада воюет немало моджахедов, половина из их командиров - полевые командиры боевых ячеек Аль-Кайды. Дело дошло до того, что американский госдепартамент в марте 2013 года выразил глубокую озабоченность этим фактом, предложив ЦРУ и РУМО вычислять лидеров террористов и исламистов, воюющих против режима Асада, и уничтожать их точечными ударами с помощью беспилотников. Если их послушать, то можно прийти к выводу о том, что и сама война против Асада была развязана Соединенными Штатами с единственной целью - собрать всех наиболее опасных террористов и исламистов в одном месте, с тем, чтобы потом не бегать за ними по всему Большому Ближнему Востоку.

Вместе с тем, сами исламисты связывают революции «Арабской весны» не с победой демократии, а с новым рождением ислама. Их официальная пропаганда рисует совсем иную картину всеобщей победы: исламисты открыто заявляют о начале построения нового мирового порядка, основанного на исламских ценностях, в котором не будет место таким пережиткам мировой истории, как христианская культура и т.д. И это не пустые слова: повсеместно в регионе, зачищенном волной «Арабской 
весны», исламисты приходят к власти благодаря умелой игре на амбициях европейских лидеров (Кемерона, Саркози) и умением встроиться в ближневосточную политику Соединенных Штатов, решающих в волне «управляемого хаоса» определенный набор частных прагматических задач и не заглядывающих в будущее региона. С точки зрения исламистов, американские протестанты и их союзники выполняют важную миссию «зачистки» политических режимов региона, которые попытались отойти от устоев воинствующего ислама и внедрить в мусульманской среде светские формы правления. То есть, западными демократиями умело пользуются.

Сегодня, спустя два года после начала революций в арабском мире, некоторые натовские союзники США, такие как Великобритания и Франция, начинают постепенно приходить в себя и называть вещи своими именами: они отмечают, что «Арабская Весна» на практике обернулась для Запада «Христианской Зимой» ${ }^{2}$. Действительно, везде, где революции победили, к власти пришли исламисты. Англосаксы и их европейские союзники демонтировали основы светской политической системы в целом ряде арабских государств, вся предыдущая история которых в принципе не знала светских форм правления. Таким образом, за короткий интервал времени историю удалось обратить вспять. Еще недавно исламисты о таком повороте событий не могли и мечтать. Теперь же это стало объективной реальностью.

Откровения европейских союзников Соединенных Штатов, сравнивающих «Арабскую весну» с «Христианской Зимой», напоминают известный всем медицинским работникам процесс абстиненции, или - похмелья: теперь, когда первоначальный эффект всеобщей эйфории от участия в формировании нового миропорядка уже спал, в их сознании появляется понимание того, что американцы, решив свои вопросы с Ираном и Китаем, из региона уйдут, оставив у границ объединенной Европы почти сформировавшийся новый Халифат, сцементированный исламским ревизионизмом и располагающий успевшей подрасти в гражданских войнах в Ливии и Сирии новой ваххабитской пехоте, с помощью которой он будет продолжать расширяться на Запад - за счет территории Европейской цивилизации (и вот здесь-то Дании и вспомнят карикатуры на пророка Мохаммеда), и

2 Filiu J.-P. The Arab Revolution. Ten Lessons from the Democratic Uprising. / London: Hurst \&Co. 2011. 195 p. на север - в сторону России. После хозяйничания американцев в регионе останется много проблем, и по старой традиции, все они достанутся европейцам, которые на этот раз окажутся в кольце воинствующего исламизма. В свое время пример Косово убедил не многих. Теперь прямые последствия «Арабской Весны» будут выглядеть намного более убедительными.

\section{II. СЕВЕРНАЯ АФРИКА И БЛИЖНИЙ ВОСТОК: ЦВЕТНЫЕ РЕВОЛЮЦИИ АРАБСКОЙ ВЕСНЫ}

\section{Революции «Арабской весны»: признаки неслучайности}

В недавней волне революционных событий, прокатившейся по Ближнему Востоку и Северной Африке и успешно демонтировавшей целый набор политических режимов, казавшихся раннее абсолютно стабильными и незыблемыми, обращает на себя внимание ряд особенностей.

Во-первых, все они развивались (а в случае с Сирией - продолжают развиваться) по одному и тому же сценарию, или «революционному» шаблону, очень похожему на сценарии «цветных революций». В частности, технологии организации и работы с молодежным протестным движением, включая революционный брендинг, в революциях «Арабской весны» полностью копируют аналогичные технологии цветных революций в СНГ и других регионах политической карты мира.

Во-вторых, «революции» в различных государствах Северной Африки и Ближнего Востока вспыхнули практически одновременно, что практически всегда исключает любой элемент случайности и предполагает высокий уровень координации (по времени) из зарубежного «революционного центра», либо - факт проведения тщательно спланированной внешними силами специальной операции.

В-третьих, причиной «пожара», погрузившего в политический хаос самую стабильную и «европейскую» страну - Тунис, стал совсем незначительный повод: самосожжение местного жителя. Тем не менее, это сразу послужило сигналом для начала вооруженного мятежа, в считанные дни охватившего всю страну.

Вместе с тем, организация мятежа практически невозможна без тщательной предварительной подготовки, вербовки боевиков и сплочения их в боевые группы, четкой системы координации, материального обеспечения и, самое главное, - аккумулирования в зоне будущего конфликта значи- 
тельных финансовых средств, предназначенных для подпитки «революционной борьбы». Последнее невозможно доставить в зону конфликта мгновенно, и уж тем более, если мятеж уже начался. Без внешней финансовой поддержки ни одна из современных «революций» не имеет ни шанса против законной власти.

В-четвертых, «пламя революции» охватило государства Ближнего Востока и Северной Африки по очереди, строго в определенном порядке, что также наводит на мысли: в природе лесной или степной пожар распространяется круговой волной, захватывая все прилегающие территории, если, конечно, его никто специально не направляет в нужную сторону. Здесь же налицо явная избирательность: Тунис-Египет-Ливия-Сирия-Бахрейн-Йемен и т.д. При этом в стороне остались Алжир, Марокко и др. африканские страны, имеющие сходные социальные проблемы и отличающиеся таким же «консерватизмом» политических режимов.

В-пятых, в «революциях» на Ближнем Востоке и в Северной Африке наблюдается еще один ключевой элемент технологии «цветных революций»: это - механизм обратной связи, обязательно присутствующий в любой специальной операции. Суть его такова: первоначальный сценарий «революции» обкатывается на примере одной страны, затем корректируется (с помощью механизма обратной связи) и в виде очередной итерации запускается в отношении следующей по списку страны. Затем процедура коррекции повторяется снова. При этом соблюдение очередности в применении технологий «революций» к избранным странам обязательно: такой прием позволяет вовремя учитывать и исправлять ошибки в исходном сценарии, оперативно адаптировать его под тонкую специфику региона, которая проявляется, как правило, уже в процессе реализации исходного замысла. В этом - гибкость современных технологий «цветных революций» и, одновременно, их главный демаскирующий признак.

И, наконец, во всех «революциях» в странах Ближнего Востока и Северной Африки настораживает один факт: странное отсутствие обязательного компонента любой революции - революционной идеологии. Настоящие революционеры - идеалисты: в основе их революционной борьбы лежат либо высокие идеалы (свобода, равенство, братство, справедливость), либо идеи национально-освободительных движений. Между тем, ничего подобного в арабских «революциях» нет и в помине: есть разношерстное протестное движение, которое быстро превращается в «политическую толпу», основная цель которой - свержение действующей законной власти в лице ее конкретных представителей, с одной стороны, и погромы - с другой. При этом «революционная» толпа не выдвигает никакой альтернативной политической программы. Обладая этим ареалом, эти люди могут не иметь ни известного прошлого, ни заслуг перед страной, и вообще вынырнуть из политического хаоса в самый последний момент. Для любых мировых лидеров, интересы которых лежат в данном регионе, этот момент является самым лучшим для приведения к власти своих ставленников.

Отсутствие революционной идеологии выдает в событиях на Ближнем Востоке в Северной Африке почерк, характерный для англосаксов и проводимых ими специальных психологических операций.

Так, технологии «цветных революций» хорошо известны и обкатаны на примере нескольких десятков стран, в том числе - государств Центральной Азии, имеющих преимущественно мусульманское население. Хорошо известна предпринятая недавно британцами и американцами попытка организации «зеленой революции» в Иране. Однако, в отличие от стран, ориентирующихся на западные либеральные ценности и психологию индивидуализма, шаблонная идеология «цветных революций» не работает в традиционных восточных обществах: на Востоке, где сохранился общинный и родовой уклад жизни, интересы отдельной личности - ничто, а интересы общины - всё.

Человек на Востоке никогда себя не реализует вне общины, к которой принадлежит: оторвавшись от общины, его ждет полное забвение и, в конечном счете, гражданская гибель. Вместе с тем, община дает человеку очень многое, в первую очередь - поддержку и защиту, нередко даже в большей степени, чем это может обеспечить его западному коллеге либеральное государство. В этом плане свобода на Востоке понимается совсем не так, как на Западе: это не личная свобода от каких либо запретов и ограничений, а свобода пользоваться возможностями и ресурсами общины для того, чтобы принести своей общине и в конечном итоге, себе лично, еще большее процветание. В этом пане идеология цветных революций несет прямую угрозу свободе личности, живущей в традиционном восточном обществе, ее родным, близким, семье. Одним словом, западный лозунг «свобода» не находит отклика на Востоке.

Таким образом, для любых западных политтехнологов, намерившихся сделать арабские страны площадкой для обкатки своих новых «революци- 
онных» технологий, задача выбора подходящей к текущей ситуации в регионе революционной идеологии становится неразрешимой проблемой. В этом случае специалисты специальных операций опускают вопрос идеологии вообще, заменив его набором внешних пиар-клише и положившись на быстрое формирование из массы недовольных «политической толпы», для которой идеология не нужна вовсе, а необходимо лишь указать цель и направление главного таранного удара. Между тем, у настоящих революций, являющихся истинным проявлением воли народа, идеология есть всегда. Все эти признаки указывают на некую искусственность в наблюдаемых сегодня «революциях» в Северной Африке и на Ближнем Востоке, оставляя полагать, что здесь не обошлось без внешнего «дирижера».

Важной особенностью революций «арабской весны» стало применение новейших сетевых технологий, связанных с новыми возможностями использования социальных сетей и блогов, таких как Twitter и Facebook, что тоже в определенной мере выдает в арабских революциях «западный почерк». Однако, некоторые известные политологи, такие как А.М. Васильев, директор Института Африки РАН, отрицают внешний сценарий у революций «арабской весны», ища причины событий среди факторов экономического или демографического характера. Васильев ставит во главу угла демографический пик, в результате которого сегодня в арабских государствах большинство населения составляет молодежь в возрасте от 18 до 33 лет, которая легко и охотно объединяется в любые протестные движения, в том числе направленные против действующей власти. В этом, по его мнению, и состоит революционная ситуация, а вовсе не в состоянии экономики и качестве жизни, которые при пристальном рассмотрении вовсе не представляются катастрофическими для норм жизни данного региона. Тем самым он в известной мере подвергает сомнению причины арабских революций, связанные с социальным неравенством, нищетой и «усталостью» населения от несменяемых политических режимов.

Вместе с тем, нельзя не отметить тот факт, что условия, при которых США вмешались в военный конфликт в Ливии, оказались весьма удачными для создания вокруг Вашингтона ореола спасителя европейской коалиции, стоящей в тот момент на пороге военной катастрофы: как показаили первые четыре месяца войны, ни французы, ни англичане не оказались на деле способны сломить сопротивление войск Каддафи. В тот момент, когда для франко-британской коалиции дела приняли весьма неудачный оборот, Вашингтон пришел на помощь своим союзникам, не бросив их в беде и включившись своими силами в военные действия, которые, согласно официальной легенде, Белый Дом всеми силами стремился избежать. Впервые после высадки в Нормандии 1944 г. Вашингтон выступил в роли спасителя Европы (в лице их экспедиционных сил на ливийском театре военных действий) и одновременно предпринял убедительную попытку доказать всему миру, что это не он развязал войну против Ливийской Джамахерии, а его насильно втянули в конфликт неудачные действия союзников по блоку НАТО, помимо собственной воли и в силу неудачно сложившихся (для европейских союзников США) обстоятельств. То есть, США появились в Ливии не по своей инициативе, а потому, что их настойчиво «попросили». Теперь на Америку стали смотреть с надеждой, что именно она внесет решающий вклад, благодаря которому ситуация переломится. В этих условиях, когда общественное мнение «созрело», для США настало время сыграть «ключевую роль». Подтверждением существования таких намерений стали комментарии в американских СМИ: «нагрузка на британские и французские вооруженные силы растет, .... у президента нет веских оснований отказывать в просьбе союзникам, кроме стремления провести идеологическую линию о том, что Соединенные Штаты не обязаны возглавлять каждую военную интервенцию НАТО. Эта линия была проведена. Теперь настало время сделать то, что возможно, чтобы приблизить окончание ливийской войны» (New York Times. May 10, 2011).

В этой комбинации, искусно разыгранной Вашингтоном, налицо явное манипулирование двумя не совсем адекватными политическими фигурами - Н. Саркози и Д. Кэмероном, которых сначала подтолкнули к тому, чтобы развязать военную интервенцию против Ливийской Джамахирии (воздействуя на их непомерные амбиции и тщеславие), подождали, пока европейские силы увязнут в войне и начнут получать чувствительные удары от правительственных сил, а затем пришли спасать то, что от франко-британских сил еще осталось. Ливийскую карту разыграли не по французскому сценарию, а по американскому, хотя у Саркози на начальном этапе военной операции такой сценарий определенно был. Французами и британцами попросту воспользовались «втемную», искуссно манипулируя их весьма внушаемыми и увлекающимися лидерами. 


\section{Международные отношения / International Relations}

\section{Технологии политических переворотов и «управляемого хаоса»}

Технологии «финиковых» и «фисташковых революций» имеют несомненное сходство с «цветными революциями», используя все тот же арсенал психологических и организационных приемов, шаблонов и схем, но смещая при этом ударение на методы, способные расколоть сплоченность традиционных восточных обществ на мелкие фрагменты, с тем чтобы вырвать отдельных личностей из состава родовых и племенных кланов, дезориентировать их в политической обстановке с помощью технологий управления массовым сознанием и создать из этих дезориентированных граждан главный таранный инструмент любой «цветной революции» - «политическую толпу». Методы и технологии, позволяющие расколоть сплоченные традиционные общества на отдельные фрагменты, погружая общество в состояние распада и политический хаос, подчиняющийся своим законам, носят название технологий «управляемого хаоса». След применения именно этих технологий в Северной Африке и на Ближнем Востоке усматривают сегодня многие эксперты и обозреватели.

Одним из авторов популярной на Западе «теории управляемого хаоса» является американский стратег, дипломат и политолог Стивен Манн. Суть выдвигаемой им концепции следующая.

Цель любой специальной психологической операции - обеспечить добровольную подчиняемость представляющего интерес человека с тем, чтобы впоследствии свободно и без каких либо ограничений использовать его в своих целях - в качестве неодушевленного инструмента, ресурса, расходного материала. Этот результат сравнительно несложно обеспечить в западных либеральных обществах, где каждый гражданин - индивидуалист, в жизни преследует исключительно личные цели, и, хотя и пользуется в некоторой мере поддержкой и защитой государства, в основном борется и выживает в одиночку. Такого индивидуума несложно психологически сломить и «перепрограммировать» под любой шаблон политического поведения, включая т.н. «демократический», поскольку ни одна даже самая сильная личность не в состоянии выстоять перед напором системы и применяемыми ей технологиями психологического убеждения и принуждения. Вот почему в Западном обществе так популярны и эффективны многочисленные техники скрытого манипулирования, «промывки мозгов», НЛП, рефлексивного управления, а секты сравнительно просто вербуют и обрабатывают адептов. Ведь для того, чтобы заполучить себе адепта, необходимо всего лишь взломать его личные защитные барьеры, которые обеспечила ему природа при рождении для защиты психики от внешних негативных воздействий, и заменить его систему ценностей своей.

В традиционных обществах с коллективной субъектностью все иначе. Там отдельная личность, глубоко интегрированная в общество, клан, род или племя, защищена этим обществом от любого внешнего негативного психологического воздействия, даже самого мощного. В противодействии негативному влиянию или любой формы информационной агрессии любой член этого обществ может рассчитывать и опираться на ресурсы всего общества в целом и на помощь любого из его членов, поэтому его не так просто сломить. Для этого необходимо разрушить внешний рубеж обороны - саму традиционную структуру построения общества - и погрузить общество в политический хаос, который лишает любого попавшего в его водоворот человека коллективной поддержки и превращает его в индивидуалиста, озабоченного исключительно вопросами своего собственного выживания. Рецепт погружения обществ в хаос прост: это - политический переворот или вооруженный мятеж, сопровождающийся мощной информационно-пропагандистской компанией по дискредитации традиционных ценностей. Такой процесс приведет к стремительной «атомизации» закрытого традиционного общества с коллективной субъектностью в основе своего устройства, что в итоге «откроет» его, перемешает. В результате разрушения традиционного уклада и девальвации ценностей возникнет идеологический вакуум, который сразу же должен быть заполнен специально разработанной режиссерами «революций» идеологией. Смена ценностей в условиях хаоса произойдет незаметно: любая личность, вырванная из своего традиционного уклада и потерявшая поддержку своего рода или клана, будет хвататься за любую идеологическую концепцию, гарантирующую ей выживание. Происходящая в этом процессе смена системы ценностей в обществе обеспечивает добровольную подчиняемость всех его членов и превращает общество в послушный инструмент реализации внешнеполитических интересов иностранного государства. Хаос становится управляемым.

В соответствии с этой теорией, для обеспечения добровольной подчиняемости стран Ближнего Востока и Северной Африки интересам внеш- 
него государства, объединяющие их население кланы и общины должны перемешаться, т. е. нынешнее, традиционное социальное устройство, которое на Ближнем Востоке и в Северной Африке существует до сих пор, должно быть разрушено и перемешано. Именно это и происходит сейчас в государствах, ставших жертвами «новой революционной волны».

\section{Ливийская кульминация «Арабской весны»}

Сегодня, наблюдая конфликт в Сирии между правящим политическим режимом и действующими от имени основной массы сирийского народа хорошо организованными мятежными группами боевиков, многие задаются вопросом: будет ли ситуации в Сирии развиваться по ливийскому сценарию, погрузив регион в хаос гражданской войны и военной интервенции. Эти опасения не случайны.

Война в Ливии уже показала, насколько быстро в современных условиях отдельные робкие выступления слабых и разрозненных групп недовольных правящим режимом могут перерасти сначала в вооруженные столкновения, а затем - и в гражданскую войну, быстро превратившуюся, благодаря прямому военному вмешательству западных государств, в крупный международный конфликт. Между тем сегодня ситуация в мире настолько накалена, что любой международный конфликт может стать поводом для новой мировой войны. Цель любой мировой войны - передел политической карты мира, исторически сложившихся государственных и национальных границ. И не важно, о каких именно границах идет речь, о «морально устаревших» границах бывших европейских колоний или о новых геополитических рубежах и «демаркационных линиях» между «мировыми цивилизациями», очерчивающими их «природное жизненное пространство»: одно с легкостью может перетечь в другое. С другой стороны, именно к такому переделу мира стремятся сегодня Соединенные Штаты, сознательно демонтирующие ялтинско-потсдамскую модель и ведущие риторику о необходимости пересмотра «искусственных и нежизнеспособных» границ бывших европейских колоний и осколков Османской империи, показавших, по мнению Вашингтона, свою несостоятельность в роли самостоятельных субъектов мировой политики. В этом процессе Ливия и Каддафи - всего лишь повод для нового передела мира, а военная интервенция - окончательный аргумент для тех, чье мнение игнорируется, в том числе - для коренного населения бывших колониальных стран. Понимая, что тем самым Соединенные Штаты ставят мир на грань глобального вооруженного конфликта и сознательно раскачивают систему международной безопасности, Вашингтон все-таки надеется новой мировой войны избежать.

Можно указать на общие черты между политическими режимами Ливии и Сирии и на схожесть их политического курса. И Дамаск, и Триполи открыто демонстрировали свою оппозицию Израилю и Вашингтону. Сирия, к тому же, поддерживает ливанскую «Хизбаллу» и палестинский ХАМАС, является фактически единственным в регионе союзником Ирана. Это позволяет утверждать, что повторение в Сирии ливийского сценария весьма вероятно. Башар Асад молод, энергичен и может рассчитывать на поддержку как алавитов, так и значительной части христианского населения. Он не откажется от власти добровольно, также как и Каддафи. В его распоряжении одна из самых боеспособных армий в регионе и мощный аппарат госбезопасности: режиму есть чем ответить на любую внешнею агрессию. Сирийская оппозиция разрознена, а гражданское общество не так активно, как в других странах Ближнего Востока или Северной Африки.

Волна «цветных революций», сметя тесно связанные с Вашингтоном режимы Туниса и Египта, явно забуксовала в Сирии: так всегда происходит с цветными революциями, если лидеры страны способны повить твердость и жесткость в сложившейся ситуации. Так было во время цветной революции в Узбекистане, когда действующая власть объявила выступление боевых групп «оппозиционеров» в Андижане вооруженным мятежом и жестоко подавила его с помощью верных режиму воинских частей. И в том и в другом случае момент упущен: залп цветными революциями уже состоялся, но мгновенного результата (в отличие от других стран) он не дал. В этом случае авторы цветных революций всегда уходят в тень и маскируют свое участие в политических событиях (поскольку с каждым днем промедления значительно возрастает риск раскрытия любой проводимой ими операции), уступая место силам, предназначенным для прямой вооруженной агрессии, которые вводятся в регион для вооруженной поддержки боевых групп мятежников под прикрытием легенды о силовом умиротворении или гуманитарной интервенции. Вот почему развитие ситуации в Сирии по ливийскому сценарию представляется не только весьма вероятным, но и неизбежным. При условии, ко- 
нечно, что Вашингтон не готов отказаться от некоторых своих планов по «переформатированию» Ближнего Востока, касающихся этого государства.

Между тем, падение сирийского режима имело бы огромные последствия: профессор женевского Института высших международных исследований Мухаммед-Реза Джалили утверждает, что, наряду с Египтом Сирия является одним из двух полюсов арабского Востока, и с падением режима Асада вся система альянсов в Леванте рухнет, а Иран лишится своего единственного союзника. Это совпадает с одной из основных целей США, которые рассчитывают из управляемого хаоса, в который с помощью технологий финиковых революций погрузился Ближний Восток и Северная Африка, сформировать ту конфигурацию международных отношений, которая наиболее отвечает их собственным интересам, и в которой, возможно, уже не будет места для Ирана, Китая, а влияние России будет жестко ограничено.

На это прямо указывает заявление сенатора Д. Маккейна, сделанное им 24 августа 2011 года. Известный своими жесткими высказываниями, сенатор от штата Аризона Джон Маккейн выразил удовлетворение взятием повстанцами Триполи и концом режима Каддафи.

Говоря о последствиях падения режима Кадда$ф и$, Д. Маккейн выразил мнение, что смена власти в Ливии даст сигнал и другим странам, «стремящимся к демократическим преобразованиям»: «это будет своеобразным посланием и для Башара Асада, и для Йемена, и для других диктаторов. Эхо «арабской весны» услышат во всем мире - от России и Китая до Израиля. С тех пор как молодой человек сжег себя на улице, положив начало волнениям в Тунисе, мы видим стремительно меняющийся мир», - заявил Маккейн. Таким образом, Маккейн не исключает, что следующей целью волны «финиковых революций» будет Китай и Россия.

\section{Сирия}

В целом, ситуация в Сирии сегодня развивается в полном соответствии со сценарием, отработанным в Ливии. В развитии сирийской и ливийской «революций» есть все признаки схожести:

- и организация протестного движения внутри страны, которое напоминает массовую кампанию вербовки наемников;

- $\quad$ и выдвижение на роль новых лидеров государства малоизвестных деятелей из числа эмигрантов (таких как кабинетный ученый Гальюн, постоянно проживающий в Париже), единствен- ная ценность которых - полная управляемость и преданность своим западным кураторам;

- $\quad$ и создание всевозможных «теневых кабинетов министров» и псевдонародных «фронтов», таких как «Патриотическая коалиция в поддержку демократических перемен», «Национальный Совет Сирии», позиционирующий себя как истинные представители народа и руководящие органы многочисленной внутренней оппозиции, недовольной режимом Асада.

Все это известные элементы технологии организации цветных революций, отработанные в конфликтах в Югославии, Грузии, Украине, странах Центральной Азии, которые сегодня адаптированы для применения в традиционных восточных обществах, принадлежащих в основном исламскому миру: в арабских государствах Ближнего Востока и Северной Африки, в Иране. Цветная революция в Сирии в целом развивается по ливийскому сценарию. Но стоит отметить, что и сама ливийская «революция» стала повторением и дальнейшим развитием технологических схем организации государственных переворотов, отработанных несколько раннее в Тунисе и Египте. В «революциях Арабской весны» явно прослеживается итерационная схема, в которой один и тот же шаблон последовательно применяется по отношению к различным арабским странам, каждый раз после завершения операции подвергая ее схему реализации технологической коррекции. В отличие от ливийской «революции», ситуация в Сирии развивается несколько менее динамично, но на это есть объективные причины. Ее относительная вялясь вызвана, прежде всего, тем, что западные политтехнологи перед началом решительных действий (применения технологий «управляемого хаоса», так хорошо показавших себя в Тунисе, Египте и Ливии) заручиться поддержкой или нейтралитетом армии (для этого надо хотя бы немного продвинуться в ее разложении), с которой уже ведется активная работа по агентурным каналам, а также навербовать «оппозиционеров» для участия в массовых акциях протеста и боевиков для наступательных и диверсионных действий. Видимо, развитие революции тормозят причины чисто технического характера: необходимость тайно (от сирийского руководства и надзора мирового сообщества) перебросить в распоряжение оппозиционных сил внутри страны необходимые финансовые средства и оружие. Сирийское руководство не испытывает никаких иллюзий в отношении внешней подоплеки событий, происходящих в стране. 
Сегодня уже очень многие исследователи говорят о революциях Арабской Весны, внезапно - в конце 2010 года - охвативших всю Северную Африку и практически весь Ближний Восток. В результате этого взрыва довольно стабильный и внешне мало изменчивый арабский мир рухнул и погрузился в пучину хаоса, мятежей и гражданских войн. Эффект от революций на Ближнем Востоке оказался настолько сильным и шокирующим, что многие исследователи и очевидцы стали искать в установившемся в регионе хаосе войны всех против всех (суннитов против шиитов, исламистов против светской власти, террористов против сил антитеррора и т.д.) следы внешнего управления и весьма успешно их находят. Да, в общем-то, сценаристы этих революций особо и не скрываются, видимо, рассчитывая получить за Ливию, Сирию или Египет Оскара. Другие стремятся идеализировать ситуацию, одновременно ее упрощая: списывая все происходящее на причины, которые давно уже назрели в арабском обществе и только ждали момента, когда их прорвет. Этот наивный взгляд популярен, поскольку позволяет, наконец, вздохнуть с облегчением, найдя простые ответы сразу на все вопросы: не нужно задаваться неудобными вопросами, все произошло само собой. Однако, и у этой категории экспертов не все клеится. Ведь просуществовал же в Ливии более 40 лет режим «диктатора и кровавого палача» Каддафи, с которым ничего не могли поделать несколько последовательно сменившихся на своем посту президентов США, с их армией, спецслужбами и отдельным корпусом морской пехоты, который сам напоминает современную армию вторжения, только в миниатюре. Ведь трудно же принять версию о том, что этот режим рухнул всего лишь за неполный 2011 год только потому, что окончательно «сгнил изнутри».

Мы живем в непростое время: мир стремительно меняется непосредственно на наших глазах. Темпы и скорость этих изменений непрерывно растут: всего один год потребовался западным политтехнологам для того, чтобы превратить спокойную и процветающую Северную Африку и большую часть Ближнего Востока в очаг жесточайшей гражданской войны, международного терроризма и радикального исламизма. Теперь такая же участь ждет Сирию, а вместе с ней и весь Ближний Восток, включая главного непримиримого оппонента США - Иран.

Сегодня отчетливо видно, как в результате осуществляемого Соединенными Штатами сознательного демонтажа ялтинско-потсдамской системы мироустройства рушится вся система международной безопасности, мир стремительно погружается в хаос больших и малых войн, этнополитических и религиозных конфликтов. Деятельность США, их партнеров (НАТО, Саудовкая Аравия, Катар) по «силовому умиротворению» и «принуждению к демократии» в различных регионах мира не только не устраняет первопричины протекающих там политических конфликтов, но во многих случаях приводит к их эскалации и переходу на новый, более масштабный, уровень. При этом в большинстве стран, во внутренние дела которых США вмешиваются в роли «миротворца», они делают ставку и сотрудничают с теми самыми политическими силами и режимами, которые во всем мире принято называть «террористическими» и «экстремистскими». Так, в Афганистане США активно сотрудничают с талибами (на уровне самых настоящих партнерских отношений), а в гражданской войне в Ливии решающую роль в уничтожении армейских частей, верных Каддафи, сыграли боевые отряды Аль-Кайды, стоявшие на острие удара, нанесенного совместно силами НАТО и мятежников. И сейчас среди полевых командиров так называемой объединенной сирийской оппозиции не менее половины - руководители боевых ячеек Аль-Кайды, вышедшие из подполья, в которое их загнал президент Башар Асад.

По всем основным и квалифицирующим признакам, так называемые революции «Арабской весны» - это типичные цветные революции, адаптированные под условия традиционного исламского общества.

В целом в ситуации на Ближнем Востоке в контексте революций «Арабской весны» сирийский вопрос продолжает оставаться неясным. С одной стороны, гражданская война в Сирии начинала развиваться как типичная цветная революция, по сценарию, сходному с ливийским. С другой стороны, с Сирией все должно было закончиться еще до первых чисел мая 2012 г.: в этом в самом начале 2012 года были уверены абслютно все, и друзья, и непримиримые противники режима Башара Асада. Американцы - авторы классических цветных революций, только что успешно обкатавшие свой «демократический шаблон» на примере Ливии, настолько в этом не сомневались, что даже начали разворачивать аналогичный сценарий в России, в которой эти волнения, местами закончившиеся незначительными беспорядками, получили название «революции белых ленточек». Тем было удивительнее, когда из Сирии очередной сенсации не вы- 
шло: режим Асада неожиданно проявил стойкость и решимость бороться за власть до конца, не считаясь с потерями среди своих соратников и мирного населения. И волна очередной революции забуксовала в считанных километрах от президентского дворца, получив несколько весьма ощутимых уроков как в самой столице, так и в боях в жилых кварталах Алеппо, Хомса. В результате сирийский мятеж, вовремя не поддержанный иностранной интервенцией (как это было в Ливии), превратился в затяжную позиционную гражданскую войну, в которой самые тяжелые потери несет мирное население. Дошло дело даже до того, что «освободившиеся» после гибели Каддафи ливийские боевики перетекли в основном не в Сирию, где полным ходом идет дело освобождения народа от власти очередного наследственного диктатора, а в Мали, где они, сговорившись с туарегами, организовали исламистский переворот. Вот и стоит задуматься, за что воевали эти «революционеры» - за светлые идеалы англосаксонской демократии, универсальные общечеловеческие ценности или прибыль, которую можно получить, установив власть над страной, обладающей богатейшими залежами урана. Мали, правда, географически расположена ближе, чем Сирия (в случае чего можно и пешком дойти), но это не помешало американцам в начале первого наступления Сирийской свободной армии на Дамаск перебросить в район боев около 700 оставшихся не у дел ливийских боевиков. Так что было бы желание, а способ всегда найдется.

Причину столь упорного сопротивления режима Асада численно превосходящим силам мятежников (в гражданской войне на стороне Асада воюют только алавитские части и специальные службы, остальная армия выжидает и фактически бездействует) многие эксперты видят в наглядном примере, преподнесенном Каддафи: его гибель в очередной раз показала, что американцы и их союзники не планируют оставлять в живых свидетелей своей тайной политики на Арабском Востоке. Как бы не сложилась ситуация в Сирии, живым Асада из страны не выпустят, и он это вполне отчетливо понимает: Асад, хотя и является представителем сугубо мирной профессии - по образованию он врач-офтальмолог, но впечатление наивного человека ни в коей мере не производит. Особенно, если учитывать тот факт, что точно такая же угроза исходит из его алавитского окружения, настроенного сражаться до конца, среди которых Асад выглядит удерживаемым заложником. С этими доводами, конечно, трудно не согласиться, но вместе с тем, сто- ит отметить, что на этом причины сопротивления правящего режима Сирии не исчерпываются, потому что Сирия - не Ливия, а Асад - не Каддафи.

Сходство между войной в Ливии и Сирии наблюдается только в качественном составе мятежных формирований, противостоящих правительственным силам: в большинстве своем это все те же исламисты-моджахеды (как правило, граждане других государств), разбавленные профессиональными наемниками (не имеющими убеждений) и дезертирами из правительственной армии и полиции. На этом сходства заканчиваются, потому что противостоят сирийским мятежникам силы, качественно отличающиеся от тех, с кем Каддафи начал войну.

Если за Каддафи воевали в основном люди его племени - из родного для него города Сирта, население которого в буквальном смысле разделило участь вождя, то за Асада воюют алавиты - приверженцы одного из шиитских направлений в исламе, для которых победа оппозиции, состоящей в большинстве своем из суннитов, означает поголовное физическое истребление, то есть геноцид. Именно так сирийские повстанцы и поступали с мирным населением, если им удавалось захватить алавитское селение или деревню. Заодно по маршруту движения Свободной Армии Сирии вырезались и остальные конфессии - в основном, христиане. Последний христианин в г. Хомс, перешедшем под контроль мятежников в конце 2012 года, был убит тогда же, 1 ноября 2012 г.

В отличие от алавитского ядра сирийской армии, которая считается одной из самых боеспособных в регионе, армия Каддафи состояла в основном из наёмников. Которые и отошли в сторону, как только в конфликт вмешались США, тем самым спасшие своих союзников по НАТО - Францию и Великобританию - от весьма вероятного военного поражения. На комплексах ПВО у Каддафи сидели в основном пакистанцы, которых трудно заподозрить в наличии излишнего патриотизма в отношении чужой для них страны и упорного желания воевать за маленький (всего около 2 млн. населения) ливийский народ.

Боевые действия мятежников из Свободной армии Сирии и воюющих на их стороне боевых подразделений Аль-Кайды, Талибана, Движения исламского возрождения Узбекистана и других, до сих пор не поддержаны прямой иностранной интервенцией, хотя попытки ее начать, инсценировав формальный повод, все-таки делались: одной из таких попыток следует считать обстрел неустановленными лицами, находящимися на сирийской 
территории, турецких пограничников, повлекший жертвы среди мирного населения. Второй попыткой начать маскированное вторжение Западной коалиции можно считать «малую войну» между Палестиной (находящейся под фактическим контролем ХАМАС) и Израилем, обвинившем Иран и Сирию в поставке боевикам ХАМАС ракетного вооружения. Третьей попыткой найти формальный повод для начала внешней агрессии против Сирии можно считать перепевы по поводу наличия у «преступного» режима Асада оружия массового поражения - на этот раз, в отличие от Ирака, не ядерного, а всего лишь химического, - и решимости Асада это оружие применить в случае, если США и НАТО решатся на прямое участие в конфликте [8].

В первом случае сценарий оказался предельно прост: в обстреле турецкой территории обвинили сирийскую правительственную армию, в связи с чем Турция решительно заявила, что намерена решительно пресекать любые попытки нападения на ее граждан, но при этом опасается пасть жертвой прямой военной агрессии со стороны асадовского режима. В тот же день США выступили с заявлением, смысл которого сводился к тому, что США не росят своего союзника по НАТО в беде и готовы немедленно прийти к нему на помощь, невзирая на международные конвенции и резолюции СБ ООН. Не трудно заметить, что этот сценарий полностью скопирован с более раннего - ливийского, в котором США якобы были вынуждены оказать военную помощь своим союзникам по НАТО, терпящим военное поражение от «диких бедуинов», незнакомых с цивилизованными традициями ведения войны. Вероятно, именно благодаря столь явно выраженной похожести этот сценарий так и не получил своего дальнейшего развития.

Трудно не отметить, что обстрел турецкой территории неизвестными лицами, находившимися на территории Сирии, - весьма удобный повод для начала военного вторжения ударной группировки НАТО и прямого вмешательства западных государств в гражданскую войну.

Турецкая сторона приписывает нападение на своих граждан, повлекшее жертвы среди мирного населения, сирийским правительственным войскам, верным Асаду. Между тем, следует отметить, что сирийско-турецкая граница на момент инцидента уже не контролировалась правительственными войсками - еще два месяца до того она полностью перешла под контроль мятежников из Свободной Армии Сирии, о чем они сами неоднократно заявляли. Так что кто именно там открыл огонь по турецкой территории - вопрос, в целом неясный. По почерку этот инцидент скорее дело рук сирийской оппозиции, которой жизненно необходимо вмешательство в конфликт вооруженных сил североатлантического альянса: в одиночку они с Асадом не справятся. Нет сомнений в том, что ради такой поддержки они готовы пойти на любые провокации.

Кроме того, напрашивается очевидная аналогия с инцидентом, с которого началась Вторая мировая война - с расстрела немецких граждан немецкими диверсантами, переодетыми в польскую военную форму. В случае с Сирией неизвестными лицами, обстрелявшими турецкую территорию, взят все тот же шаблон, как будто его скопировали со школьного учебника. История, к сожалению, имеет обыкновение повторяться.

Во втором случае в большой политической игре, ведущейся вокруг Сирии, была разыграна карта ближневосточного конфликта между Израилем и Палестиной. 15 ноября 2012 года на Ближнем Востоке вспыхнул конфликт, имевший все шансы переродиться в новую большую войну: боевики радикального палестинского движения ХАMAC выпустили по Израилю около 400 ракет класса «земля-земля». Треть из них были перехвачены израильской ПРО, остальные попадали на головы израильтян, включая жителей их столицы. В ответ израильтяне уничтожили некоторое количество палестинцев, в основном, случайно оказавшихся в окрестностях арабо-израильской границы (СМИ говорили о 19 погибших), и объявили тотальную мобилизацию.

Пока политики гадали о причинах внезапной атаки в целом сравнительно неагрессивных (в последнее время) палестинцев на своих соседей-израильтян, сценарий новой большой войны стал приобретать вполне реальные очертания: мало кто сомневался, что Израиль обязательно ответит на атаки арабов наземной операцией в секторе Газы, перестреляет там массу случайных людей и тем самым вызовет небывалый подъем всего арабского мира.

Эти опасения имели под собой вполне реальные основания: Египет практически сразу же выразил свою крайнюю степень недовольства военными приготовлениями Израиля и, по тону заявлений тогдашего его президента, лидера египетской ячейки радикальной исламистской организации «Братья-мусульмане» М. Мурси, готов вмешаться в конфликт в любой момент. Тем более что последний в борьбе за власть незадолго перед 
этими событиями весьма изобретательно «зачистил» верхушку египетской армии, которая остается в Египте единственной реальной силой, способной влиять на политическую жизнь страны.

Интересно, что на тот момент сложившаяся вокруг палестино-израильского конфликта ситуация вполне устраивала и режим Б. Асада, и режим «исламских мулл» в Иране. Более того, не исключено, что атака ХАМАС была спланирована именно Дамаском или Тегераном и управлялась из одного из указанных центров. Впрочем, это давний испытанный способ конфликтной мобилизации в арабском мире: в борьбе против иноверцев арабы быстро забывают прежние обиды. Таким образом, если Израиль ответил на вызов ХАМАС, западная коалиция во главе с США, забуксовавшая со своей «Арабской весной» в Сирии, получила бы в качестве военного противника консолидированный фронт исламских государств. Дальнейшее развитие ситуации стало полностью зависеть от того, насколько глубоко Израиль заглотит брошенную ему наживку.

Как теперь уже известно, Израиль наживку не заглотил, и его фактическое отступление на военном и политическом фронте ХАМАС воспринял как первую свою безусловную военную победу. Однако, кто именно остановил израильскую военную машину: руководство страны или их американские партнеры, до сих пор остается неясным. Возможно, Вашингтон свернул этот сценарий, понимая, что игра становится слишком сложной и многовариантной, а сама разыгрываемая комбинация обладает рядом слабых моментов, способных сыграть на руку Сирии и Ирану.

В третьем случае сценарий оказался далеко не нов: в его основу был положен порядком уже избитый шаблонный миф об угрозе со стороны авторитарных ближневосточных режимов, якобы обладающих оружием массового поражения. Именно угроза применения ОМП режимом Саддама Хусейна (реальная или гипотетическая - сейчас уже трудно судить, ведь, как известно, наличие у Саддама ОМП не подтвердилось) стала основной причиной, оправдывающей вторжение США в Ирак в 2003 году.

В августе 2012 года Барак Обама наконец-то признался, чего он боится больше всего: химического и биологического оружия президента Асада. «Мы начнем вторжение, - заявил Б. Обама - как только сирийцы применят химическое оружие». Или куда-то его вывезут: «Если мы увидим, что химическое оружие куда-то вывозится или используется, мы будем рассматривать это как переход за красную черту. И это заставит меня действовать уже по-другому», - пригрозил Б. Обама . Но и в этом случае американцы собираются выждать, пока асадисты (сторонники Б. Асада) не истратят весь свой боезапас на «борцах за свободу». Тем из борцов, кто при этом выживет, будет дано почетное право идти впереди американских танков, первыми расчищая путь к свободе.

Российские представители заявили, что никакой химии Россия в Сирию никогда не поставляла. Запад заметно огорчился такому повороту дела: как бороться с химией русских, в принципе, понятно, она для натовских военных почти как родная, а вот что там у Асада припрятано на самом деле - доподлинно неизвестно. Так, вытащат эти сирийцы из «закромов Родины» какой-нибудь гриб - и полАль-Кайды нет.

Сирия входит в число стран, не присоединившихся к конвенции о запрещении химического оружия 1997 года. Но она его и не разрешает, не рекламирует, а бережно хранит на складах.

Близость президентских выборов в 2012 году побуждала Б. Обаму бояться сирийской химии все сильнее: лучшего момента для нагнетания всеобщей истерии было не найти, американская нация в этот период чувствительна как никогда к любым проявлениям коллективных страхов и фобий. Правительство Асада также это понимало и даже официально заявило о том, что трагедия сирийского народа предусмотрена сценарием избирательной компании действующего Президента США. Тот этого даже не стал отрицать, переключив внимание мирового сообщества на своих статистов, которых теперь стало модно держать в большой политике - Кондолизу Райс и Викторию Нуланд, которая незадолго перед этим стала новым официальным представителем Государственного департамента США.

Последняя 21 августа 2012 года выступила с заявлением, что Соединенные Штаты намерены и дальше действовать в Сирии в обход Совета Безопасности ООН, поскольку американцы сомневаются в способности некоторых членов Совета Безопасности ООН урегулировать разногласия и достичь единства мнений. «Мы будем осуществлять в Сирии настоящие политические изменения вместе с теми странами, которые хотят в этом участвовать, публично заявила В. Нуланд, - и, если потребуется, вне рамок Объединенных Наций».

Это уже не первый случай, когда простая американская девушка публично отчитывает старейшую международную организацию. В ответ на 
это заявление глава российского МИД С. Лавров заявил, что отодвигать ООН в сторону, как минимум, преждевременно: Москва и Пекин считают недопустимыми нарушения норм международного права в ситуации с Сирией. В этом мнении к министру иностранных дел России присоединился член Госсовета Китая Дай Бинго, курирующий вопросы внешней политики КНР и случайно - проездом - оказавшийся 27 августа 2008 года в Москве. По словам главы российского МИД, в своих действиях обе страны руководствуются «очень надежными критериями. Эти критерии заключаются в необходимости строго соблюдать нормы международного права, принципы, которые заложены в Уставе ООН, и не допускать их нарушения».

Что же может предпринять Башар Асад в сложившейся ситуации? На этот вопрос напрашивается несколько вполне очевидных ответов.

Во-первых, в интересах Асада сейчас перебить все боевые отряды оппозиции, пока еще они не получили поддержки в виде экспедиционных сил НАТО и государств Персидского залива. Мятежников сейчас сравнительно немного, они еще не вооружены тяжелым оружием (артиллерией, танками, комплексами ПВО и т.д.), за исключением боевых трофеев; в своем наступлении они полагаются не столько на собственную ударную силу, сколько на безграничные возможности по подкупу сирийских командиров, преграждающих им дорогу (так, как это было сначала в Ираке, а затем в Ливии).

Западу и НАТО повстанцы необходимы не как организованная боевая сила, а как некое политическое движение, которое можно выдать за представляющее интересы большинства сирийских граждан, угнетенных режимом Асада (кто там будет считать, сколько их на самом деле, этих «представителей сирийского народа», поддерживающих мятежников), избрать из их числа «правительство национального освобождения», признать его официально как единственное легитимное правительство Сирии и затем получить от лица этого суррогатного правительства официальное приглашение вмешаться в конфликт. Сходная схема была разыграна американцами на Кубе, в Заливе Свиней. Там, правда, бойцы Фиделя так быстро перебили всех высадившихся эмигрантов, что те даже не успели сформировать свое правительство, не говоря уже об установлении дипломатических отношений с соединенными Штатами. У Асада сегодня повторяется та же ситуация: пока в руках мятежников остается хоть пядь сирийской земли, для Асада сохраняется угроза прямой иностранной интервенции.
Во-вторых, Асаду неплохо бы прояснить вопрос относительно того, кто же все-таки воюет на стороне мятежников, и каков процент в их рядах собственно сирийских граждан. Есть подозрения, что этот процент невелик: известно, что примерно половина всех полевых командиров так называемой оппозиции - руководители секций Аль-Кайды, в отрядах полно исламистов из Египта, Ливии, других государств Африки и Ближнего Востока. Более того, наемники вовсю вербуются американскими инструкторами в других горячих точках планеты, например, в зоне суданского конфликта. Складывается ситуация, схожая с первой и второй войнами в Чечне, когда на стороне чеченских сепаратистов воевали моджахеды со всего арабского востока, включая страны Персидского залива; встречались даже негры. Прояснение вопроса о том, кто же воюет на стороне сирийской оппозиции, может показать реальную картину событий и указать на истинных игроков, которые сегодня на острие американской внешней экспансии несут миру новый исламский порядок.

B-третьих, у Асада явно хромает пропаганда. В рядах мятежников на него наступает Аль-Кайда, еще совсем недавно олицетворявшая собою мировое зло. На его месте давно пора бы объявить борьбу с мятежниками «контртеррористической операцией», показать тела убитых боевиков Аль-Кайды, выразить солидарность с США в борьбе с международным терроризмом и тем самым окончательно сбить с толку НАТОвских стратегов. Именно этот сценарий в свое время был так удачно разыгран российскими политиками в Чечне, где Запад тоже пытался представить чеченских бандитов «борцами за национальное освобождение от кровавого кремлевского режима». Однако, не вышло. Возможно, что не выйдет и в Сирии.

Интересно, что тема с химическим оружием получила свое новое звучание в марте 2013 года, когда власти Сирии обвинили оппозицию в обстреле позиций правительственных войск снарядами с химическими боезарядами, а официальный Белый Дом сначала выступил с отрицанием этого факта по формуле «мы не верим», а затем пригрозил лично во всем разобраться: «Я крайне скептично отношусь к подобным обвинениям в адрес повстанцев. Если окажется, что химоружие использовали правительственные войска, Башар Асад понесет за это ответственность», подчеркнул президент США Барак Обама.

Тем самым угроза миру, связанная с утратой контроля сирийским режимом над запасами ору- 
жия массового поражения, была вновь актуализирована в сознании международного сообщества. Чем не прелюдия для военного вторжения. Угроза химической войны - весьма удобный и безотказный повод для интервенции, цель которой - спасти мир от нависшей над ним угрозы химической войны. Разумеется, что ради достижения этой благой цели Сирия будет вынуждена пожертвовать своим суверенитетом, а Асад - личной властью.

Все это указывает на то, что в схемах современных цветных революций идет непрерывное эволюционирование форм и методов сопряжения психологических операций с поддерживающим их силовым ресурсом - вооруженными силами государств-демократизаторов, готовых при наличии удобного и внешне легитимного повода начать интервенцию. При этом англосаксами используется ограниченный набор шаблонных поводов, которые последовательно отрабатываются в конфликтах на Ближнем Востоке. При этом прежние шаблоны, порядком уже надоевшие (такие как угроза применения оружия массового поражения) в условиях революций «Арабской весны» могут принимать новое звучание.

Кому нужна ливанизация Сирии? Вряд ли это соответствует экономическим интересам США и Запада в регионе: режим Асада, хотя и имел некоторые противоречия с США и их союзниками в регионе, в целом всегда проявлял по отношению политики США известную лояльность и никогда не стремился ей открыто противостоять. С политической точки зрения, возможности сотрудничества с Асадом и заручения его поддержкой даже в таком сложном вопросе, как противостояние с Ираном, представлялось как вполне возможное и достижимое. Однако заказчики цветной революции в Сирии решили иначе: необходимо сместить Асада и посадить на его место марионетку, полностью зависящую от своих западных кураторов и являющуюся их политическим продуктом, как это было сделано в Ливии.

Какая причина подтолкнула их сделать именно такой выбор? Ответ на этот вопрос, возможно, может дать характер отношений США и Ираном.

В конце 2011 года из британских источников стало известно, что вооруженные силы и спецслужбы Соединенного Королевства в спешном порядке разрабатывают планы военной операции против Ирана, поскольку в их распоряжении есть информация, что США в любой момент могут нанести по нему удар; в этом случае Великобритания как основной стратегический союзник США в Европе должна поддержать армию США своими вооруженными силами, и будет вынуждена с ходу включиться в конфликт, к которому она не готова. Также стоит отметить недавний громкий скандал в Израиле вокруг утечки секретной информации по подготовке военной операции против Ирана, которую якобы слили в СМИ бывшие руководители израильской внешней разведки Моссад и контрразведки Шинбет, пытавшиеся таким образом помешать вовлечению Израиля в полностью безумную военную авантюру. Все это указывает по меньшей степени о наличии у США серьезных намерений в отношении Ирана, и то, что Вашингтон, наконец, созрел для решительного применения вооруженной силы в отношении ненавистного для него режима исламских мулл. Однако, Иран является частью исламского мира, который не останется в стороне от конфликта. Несмотря на то, что в основном арабские страны идут в одном кильватере с США, а танки Катара добровольно участвовали в военных действиях НАТО в Ливии, их позиция в отношении внезапного вторжения США в Иран наверняка не будет такой однозначной. Особенно, если Иран повторит тактику Ирака и нанесет удар по Израилю, а тот ему ответит.

Здесь становится понятна логика авторов цветных революций на Ближнем востоке и в Северной Африке: сметенные революциями режимы в Египте, Тунисе, Ливии, и находящийся под прицелом режим в Сирии, сразу перестанут быть лояльными по отношению к США, если против Ирана выступит Израиль. В результате этого в тылу американской и натовской коалиции может сформироваться «второй фронт»; сплотившая его военная необходимость может в короткие сроки превратиться в национальную идею, сплотить разрозненный и противоречивый арабский мир в новый халифат, и тогда США надолго придется отказаться от принципа «разделяй и властвуй» в арабском мире. Таким образом, цепочка цветных революций в арабских государствах и ее настойчивая реализация в Сирии носят характер «зачистки тылов» перед началом крупной военной операции в регионе, целью которой для западных коалиций может быть только Иран.

Если конечной целью режиссеров «арабской весны» является отнюдь не Сирия, а Иран, или даже Китай, который зависит от экспорта иранской нефти, то участь Сирии уже давно решена, и как бы не сопротивлялся Асад, ситуация от этого не изменится. В стратегической комбинации, разыгрываемой США в регионе, Сирия является лишь 
промежуточным звеном, ступенью, от которой зависит развитие всей операции (по подчинению Ирана и перекрытию нефтегазовых артерий Китая) в целом. Поэтому цветная революция в Сирии состоится, каких бы жертв это ни стоило: финансовых - организаторам цветной революции и человеческих - народу Сирии.

\section{Иран и Израиль}

Ситуация вокруг Ирана с каждым днем становится все более запутанной, непредсказуемой и, в некоторой степени, пугающей. Официальной причиной «закручивания пружины» напряженности, неоднократно озвученной представителями США, является нежелание иранского руководства прекратить работы в рамках своей «ядерной программы». Главные вопрос, интересующий всех, заключается в том, приведет ли очередное обострение отношений между США и Ираном к началу нового вооруженного конфликта или новой войны, которая может стать даже более масштабной, чем недавняя операция сил США и их союзников по блоку НАТО в Ливии. Внешне конфликт с Ираном развивается по хорошо известному и многократно опробованному сценарию.

Обе конфликтующие стороны постоянно высказывают весьма воинственные заявления в адрес друг друга и проводимой ими внешней политики. Так, США многократно заявляли о необходимости уничтожения источника «мирового зла» в Тегеране, представляющего угрозу существованию всей западной цивилизации, и продолжают пугать мир иранской ядерной программой, имеющей, по их мнению, военный характер. Иран, в свою очередь, не менее энергично заявляет о своей готовности к отражению любой внешней угрозы, к осуществлению решительных шагов и принесению любых жертв для защиты своего государства, вплоть до блокады Ормузского пролива, по которому проходит основной маршрут транзита ближневосточной и североафриканской нефти. И это отнюдь не громкое заявление: угроза перекрыть Ормузский пролив вполне реальна, для этого Ирану даже не нужно привлекать значительные военные силы, достаточно уничтожить один-два танкера. В результате этого разлившаяся горящая нефть сделает этот район невозможным для судоходства в течение довольно длительного времени.

Вашингтон в очередной раз разыгрывает карту с введением против Ирана новых санкций, оказывая энергичное давление на $00 \mathrm{H}$ и мировое сообщество в целом. Этим создается повод для консолидации своих союзников в некий антииранский альянс, который из экономического в любой момент может стать военным. Свежий пример применения такого приема - недавняя война в Ливии.

Израиль, чувствуя себя в центре внимания, в очередной раз предпринимает попытки выгодно воспользоваться создавшимся положением и фактом того, что именно от него, от его превентивного удара по Ирану может зависеть реальное начало вооруженного конфликта. При этом по отношению к США реализуется тактика «мягкого шантажа»: Израиль отказывается дать гарантии президенту Бараку Обаме в том, что он предварительно предупредит Вашингтон о нанесении удара по иранской ядерной инфраструктуре.

Важным фактором для развития ситуации вокруг Ирана является степень развития его ядерной программы, которая хотя и медленно, но движется к определенной поставленной цели. Качественным показателем этого движения являются успешно проведенные Ираном 2 января 2012 г. испытания новой ракеты-носителя «Гадер» с дальностью полета 200 км. Утверждается, что ракеты этого типа способны поражать цели на территории Израиля и базы США на Ближнем Востоке. По мнению МИД Великобритании, эти ракеты также могут нести ядерный заряд.

Вместе с тем, испытания этих ракет-носителей не следует рассматривать в качестве понастоящему серьезной угрозы: это еще весьма «сырые», ненадежные изделия, имеющие низкую точность и практически нулевую защиту против современных средств ПВО. В условиях реальной войны из сотни таких ракет долетит одна, которая и упадет где-нибудь на весьма значительном удалении от цели. Для создания совершенной и надежной ракеты-носителя иранцам нужно то, чего у них сегодня нет - современных технологий и достаточно длительного времени. Так что иранскую ядерную угрозу следует рассматривать, скорее всего, как миф, которым США пугают ООН и своих европейских сателлитов, но не в качестве реальной опасности.

Еще одной особенностью нынешних взаимоотношений между Ираном и США, в основе которой лежит экономический фактор, является весьма накладное для Америки содержание всех своих значительных группировок войск в Ираке и Афганистане, нацеленных для нанесения удара по Ирану. Особенно это касается содержания войск в Афганистане, где США и НАТО контролируют лишь незна- 
чительные плацдармы вокруг основных военных баз (имеющих стратегическое значение для военного контроля всего региона, не ограничивающегося только территорией Афганистана), оставив остальную территорию местной власти и талибам, от досаждающих нападений которых коалиционные силы вполне успешно откупаются. Однако, «если курок взведен, ружье должно выстрелить», т.е. в рассматриваемой ситуации эти группировки должны быть использованы по прямому предназначению. В противном случае, надо уходить из оккупированных стран, так как со временем в них начнется настолько массовое и организованное национально-освободительное движение, что американские и натовские силы оттуда могут просто не выпустить.

Вместе с тем, проблемы оппозиции в Сирии, где все еще держится режим Башара Асада, указывают на то, что время решительных действий США против Ирана еще не пришло. Американцы еще не завершили операцию по переформатированию Ближнего Востока, который в случае начала наземной операции против Ирана станет для США стратегическим, но весьма ненадежным тылом. Иран - часть исламского мира, который не останется в стороне от конфликта. Несмотря на то, что арабские страны, в основном, поддерживают США, их позиция относительно войны с Ираном наверняка не будет такой однозначной. Особенно в том случае, если Иран повторит опыт Ирака и нанесет удар по Израилю, который ему обязательно ответит.

В связи с этим становится понятна логика авторов цветных революций на Ближнем Востоке и в Северной Африке: сметенные «арабской вестной» режимы в Египте, Тунисе, Ливии и находящийся под прицелом режим в Сирии были смещены (или находятся в фазе смещения), потому что были недостаточно надежны. Более того, они мгновенно перестали бы быть лояльными по отношению к США в случае выступления Израиля против Ирана. Как результат этого - в тылу американской и натовской коалиции сформировался бы «второй фронт» из сплоченных военной необходимостью арабских стран. За короткий срок эта необходимость превратилась бы в национальную идею, которая объединила бы разрозненный и противоречивый арабский мир в новый халифат и стала бы непреодолимым препятствием для США в деле использования принципа «разделяй и властвуй» в арабском мире. Таким образом, цепь цветных революций в арабских государствах и настойчивое стремление провести такую акцию в Сирии носят явный характер «зачистки ты- лов» перед началом крупной военной операции в регионе, целью которой для западных коалиций может быть только Иран.

Следует отметить, что операция по «зачистке тылов» в определенной мере сегодня касается и России. Не секрет, что в организации протестного движения «За честные выборы» виден почерк режиссеров цветных революций, в котором наблюдаются все ее атрибуты - начиная от символики («белых ленточек») и заканчивая уровнем организации митингов и манифестаций, требующих вложения огромных финансовых средств. И совсем не случайно в Москву новым послом США был назначен Майкл Энтони Макфол, талантливый автор и режиссер «оранжевой революции» на Украине и «революции роз» в Грузии. Если нынешний сценарий «белой революции» в России финансирует Вашингтон, то делается это, в первую очередь, с одной целью: если Россия будет занята собственными проблемами, ей на определенное время будет не до Ирана. Этого времени американцам должно хватить для начала и завершения наземной операции.

В конфликте США с Ираном возможно повторение известной схемы, которую американцы достаточно качественно отработали в военной операции в Ливии: для того чтобы не выглядеть агрессорами в чистом виде (это могли позволить себе республиканцы, но не может позволить Б. Обама, избравший целью своей политики восстановление практически уже полностью утраченной «привлекательности образа американской демократии»), Вашингтон умело подтолкнул двух гиперамбициозных и черезчур честолюбивых политиков - Камерона и Саркози (двух «безумцев», как их нередко называют в европейской политике) - к развязыванию военных действий, переложив на них ответственность за этот шаг. Затем сработал верный расчет: когда в результате первых четырех месяцев военной компании силы франко-британской коалиции показали свою полную несостоятельность и оказались на грани военного коллапса, Вашингтон «вынужденно» пришел на помощь своим военно-политическим союзникам, которых США, конечно же, не могли бросить в трудном положении. Таким образом, свое вмешательство в конфликт США весьма удачно облекли в форму «морального долга» перед европейскими союзниками, совершив «благородный поступок». Точно такой же сценарий разворачивается сегодня в Сирии, где вооруженная на западные деньги оппозиция (по сути, мятежники) уже стоит на пороге того, 
чтобы втянуть во внутренний конфликт европейские страны, а затем призвать США срочно спасти от поражения и тех, и других.

В этой ситуации несколько иную игру ведет Израиль. В Вашингтоне отлично сознают, что удар Израиля по Ирану может стать тем самым спусковым крючком, который инициирует конфликт, и одновременно прекрасным поводом для вмешательства в него США и НАТО - конечно же, под предлогом защиты своего главного стратегического союзника на Ближнем Востоке. В связи с этим понятны израильские заявления в адрес Вашингтона о том, что Израиль не считает необходимым заранее информировать администрацию Обамы о своих намерениях нанести предупредительный ракетный удар по Ирану: все это может быть хорошо поставленным спектаклем, разыгрываемым для европейских союзников, России, Китая и мирового общественного мнения в целом. Понятно, что по «сценарию» Вашингтон должен оставаться в неведении относительно серьезности намерений Израиль и реальности их воплощения в действии.

\section{Вероятные заказчики цветных революций Арабской Весны}

Оставляя без внимания версию о полной спонтанности и случайности «революций» в Тунисе, Египте и других государствах Северной Африки и Ближнего Востока (которая тоже имеет право на существование), остановимся более подробно на предположении, что все произошедшее в странах Магриба и на Ближнем Востоке неслучайно и имеет внешнего заказчика. В этом случае сразу возникает несколько ключевых вопросов:

- $\quad$ как эти «революции» были осуществлены, при помощи каких схем, моделей и технологий;

- кто реальный заказчик и исполнитель «революций» в Северной Африке и на Ближнем Востоке;

- какие истинные цели преследуют «революции», кто является главной мишенью происходящих событий и зачем для поражения этой мишени понадобилось взрывать весь африканский север, отличавшийся стабильностью и устойчивостью правивших там политических режимов.

На возможных заказчиков, авторов и организаторов «цветных революций» на Ближнем Востоке указывают некоторые характерные высказывания и заявления авторов технологий «цветных революций», «управляемого хаоса» и концепции «Большой Ближний Восток». Все они - граждане США.
Так, один из авторов концепции «Большой Ближний Восток» неоконсервативный теоретик Майкл Ледин утверждает, что «современный исламский мир - это новое издание фашизма», но «фашизм играет без правил», следовательно, победить «фашизм» (т.е. исламский мир) можно только с помощью аналогичного фашизма - крайне жестких и агрессивных действий, попирающих (ради «благих» целей) некоторые основополагающие нормы демократии». В качестве ядра исламского мира, из которого исходит угроза остальному демократическому миру, он прямо указывает те самые страны Северной Африки и Ближнего Востока, где происходят сегодня события арабских «цветных революций».

В том виде, в котором существуют эти государства, они не готовы для принятия американских ценностей в виду того, что их социальное устройство представляет собой общинное, клановое, родовое, с сильно доминирующим этническим фактором. На этом фоне в большинстве из этих стран были выстроены светские политические режимы с авторитарным несменяемым лидером во главе, жесткой иерархией и зачастую режимом чрезвычайного положения, опорой на армию и спецслужбы в качестве основных гарантов соблюдения порядка и единой идеологической стройности. По своей политической форме это национальные государства с авторитарной жесткой вертикалью власти и четкой идеологической базой.

Политические авторитарные режимы, внешне демонстрировавшие лояльность США, не давали полностью открыться окружающему миру подконтрольным им территориям, что необходимо для подключения их к глобальной социальной сети. Bce это затрудняло действия американских институтов развития гражданского общества в этих странах, а формальная лояльность многих политических режимов накладывала дополнительные ограничения, заставляющие считаться с их позицией и мнением.

Теперь, по-видимому, пришло время кардинально изменить сложившуюся на протяжении последних десятилетий ситуацию. Известно, что в случае государственного переворота новая власть, состоящая из, в общем-то, сомнительных и малоизвестных международному сообществу элементов, будет в первую очередь озабочена собственным международным признанием и будет готова поступиться любыми национальными интересами ради этого. Следовательно, такое руководство будет намного сговорчивее в решении ключевых 
политических и экономических вопросов. С таким правительством можно будет пересмотреть экономические соглашения и изменить их в лучшую для себя сторону, в обмен за незначительные политические авансы в сторону новой власти.

То, что процесс погружения Северной Африки и части Ближнего Востока начался именно сейчас, говорит о том, что время пересмотра прежних соглашений правительств ряда арабских государств с такими мировыми лидерами как США (являющимися авторами указанных технологий) видимо пришло. Если за «финиковыми революциями» стоит именно Вашингтон, то переформатирование им карты Северной Африки и Ближнего Востока может преследовать две основные цели.

\section{Цели «революций Арабской весны»}

Истинные цели «революций Арабской весны» в странах Ближнего Востока и Северной Африки лежат несомненно глубже, чем просто смена политических режимов и замена, в общем то, лояльных, но малоуправляемых (в силу своей бессменности) авторитарных лидеров арабских государств на марионеток, постоянно зависимых от внешней политической поддержки. Эти «революции» необходимо рассматривать не в узком смысле, как рядовые внутригражданские конфликты, а в системе координат глобальной политики. В этой системе координат регион Ближнего Востока и Северной Африки является точкой, в которой сегодня сходятся интересы крупнейших мировых политических сил, сделавших Северную Африку своеобразным полигоном и плацдармом для приближающейся схватки за весь африканский континент, крупнейшей после получения бывшими колониями своей независимости. Эта схватка, по мнению многих аналитиков, станет для черного континента новым территориальным и энергетическим переделом.

Есть несколько важнейших причин, по которым Африка имеет стратегическое значение для мировой экономики, в том числе для геополитических интересов Соединенных Штатов Америки и Китая, как крупнейших игроков мирового рынка. Главная из них - нефть. Суммарные нефтяные резервы африканских стран-16,6 млрд. т, что составляет 10\% общемировых запасов. По этому показателю Африка уступает лишь Ближнему Востоку и Евразии. При этом новые месторождения открываются ежегодно. Лидеры по доказанным запасам нефти - Ливия $(5,7$ млрд. т), Нигерия (4,8 млрд. т), Ангола (1,8 млрд. т), Алжир (1,5 млрд. т), Судан (0,9 млрд. т). На долю За- падной Африки уже сейчас приходится 15\% нефти, импортируемой в США, и этот показатель, по всем прогнозам, в течение ближайших 25 лет достигнет $25 \%$. Нефтяные месторождения найдены на побережье Анголы, Сан-Томе, Габона и Нигерии. США пытаются уменьшить энергетическую зависимость от Ближнего Востока, поэтому Африка в последние годы стала особым объектом американского политического интереса.

На африканские страны приходится около трети китайского импорта нефти. В 2006 г. Ангола, обогнав Саудовскую Аравию, стала основным поставщиком нефти в КНР. Кроме того, экономика КНР заметно ориентируется на поставки африканского газа. Газовые ресурсы африканского континента значительны. Они насчитывают 14,65 трлн. м3, что составляет 7,9\% запасов мировых запасов. По доказанным запасам природного газа, Нигерия и Алжир (5,22 и 4,5 трлн. м3 соответственно) во всем мире уступают лишь России, Ирану, Катару, Туркмении, Саудовской Аравии, ОАЭ, но значительно опережают такого ведущего экспортёра газа как Норвегия (2,91 трлн. м3). Необходимо отметить, что в сфере энергетики КНР является крупнейшим партнёром таких африканских стран как Судан, Ангола, Нигерия, Экваториальная Гвинея и Демократическая республика Конго.

Углеводороды являются не единственным африканским сырьём, в котором нуждается КНР. Интерес также представляют руды и металлы: цинк, кобальт, медь, уран и бокситы, которые импортируются из Замбии, Зимбабве, ЮАР, ДРК, Габона и Марокко. Несмотря на то, что сам КНР располагает значительными запасами цветных металлов, большинство китайских месторождений - это бедные и не приспособленные к искусственному обогащению руды. Разрыв между ростом спроса на цветные металлы в силу бурного промышленного роста КНР и предложением в силу сокращения внутренних запасов может вызвать серьёзную проблему для экономики страны.

Таким образом, Африка и Ближний Восток сегодня являются точкой пересечения жизненно важных интересов двух великих держав - США и Китая, которые уже вступили между собой в непримиримую борьбу за доступ к энергоресурсам и политическое влияние в регионе.

Для Вашингтона страны Магриба - ключевой регион на карте мира, установление контроля над которым позволяет управлять глобальным транзитом углеводородов и других видов стратегического сырья для крупнейших развивающихся экономик (прежде всего, Китая). США в темпах эко- 
номического развития проигрывают своему главному сопернику Китаю и все больше становятся зависимыми от его быстро растущей экономической и политической мощи. В этих условиях политика Вашингтона может выражаться в том, чтобы любой ценой удержать контроль над крупными запасами углеводородного сырья, воспрепятствовать его поставке в Китай и Европу и, тем самым, сдержать их экономический рост. Один из методов достижения этой цели - использование национальных сепаратистских и экстремистских движений для дестабилизации неподконтрольных регионов - так называемый «управляемый хаос». Применение именно таких технологий и наблюдается сегодня в странах Северной Африки и Ближнего Востока, переживших или продолжающих переживать «финиковые революции». Это первая основная цель США и причина «революционных» событий в регионе: не исключено что перед новой властью пришедшей к власти с помощью технологий «цветных революций» и «управляемого хаоса» будет поставлена задача перекрыть (или существенно сократить) экспорт энергоносителей в Китай

Вторая основная цель Вашингтона может иметь отношение к приближающейся схватке за Африку и ее энергетические ресурсы в целом. Как повод для соперничества великих держав и предмет нового геополитического передела сфер влияния, Африканский континент сегодня несомненно представляет лакомую добычу. Вместе с тем в политическом плане Африка - самый молодой регион мира. Средний возраст расположенных здесь стран, кроме Эфиопии, - менее 40 лет. Подавляющее большинство государств было образовано после распада колониальных империй европейских метрополий во второй половине XX века. Не исключено, что в самом ближайшем будущим на смену колониальным границам придет новое политическое устройство региона. В этом переустройстве США рассчитывают сыграть ключевую роль выдвинув концепцию нового геополитического образовании - «Большого Ближнего Востока». Цепочка «цветных революций» в странах Северной Африки и Ближнего Востока может стать первым практическим шагом на пути ее реализации.

\section{Цели военной конфронтации с Ираном}

Несмотря на всю остроту противостояния, Иран для США не может быть стратегической целью. По большому счету, весь регион, на влияние в котором претендует Иран (Центральная Азия, часть Ближ- нево Востока), является для американской внешней политики глубокой периферией. Линия противостояния США и других полюсов современного мира, в том числе России и Китая, проходит не по Ближнему Востоку и уж тем более не по Центральной Азии, а по территории объединенной Европы.

Какие выгоды получит США, уничтожив режим исламских мулл? Влияние в регионе - возможно. Но, скорее всего, Китай займет эту нишу гораздо быстрее американцев, к тому же он ближе. Контроль над иранской нефтью - несомненно. Но компании США уже сейчас контролируют огромные запасы энергоресурсов Ирака, Ливии и ряда других стран. Иранская нефть, добытая ценой войны, им по большому счету ни к чему. Контроль над Ормузским проливом, являющимся ключевой транзитной артерией для поставщиков нефти из района Персидского залива - конечно, привлекательная цель. Однако этот контроль и так, в определенной мере, обеспечивается для США их военным присутствием в регионе и мощной группировкой военных кораблей, а также военным потенциалом союзников из числа арабских стран, доказавших свою верность в военных компаниях в Ираке и Ливии.

Ликвидация иранской ядерной программы? Вероятнее всего, для США это тоже не самоцель. Без современных ядерных технологий Иран не создаст конкурентное ядерное оружие, для которого, помимо заряда, требуется еще совершенный носитель, обладающий необходимой точностью, надежностью и способный преодолеть системы ПВО и ПРО.

Какую же цель преследуют США в противостоянии с Ираном при высокой вероятности получить еще один крупномасштабный вооруженный конфликт, который, скорее всего, будет намного больше и опаснее вьетнамского? Наиболее очевидный ответ можно найти в характере отношений США с Китаем, главным соперником и конкурентом Америки на мировой арене.

Современные отношения США и Китая описываются формулой «конструктивного сотрудничества», в которой важную роль играет парадигма мирного сосуществования двух держав. Во многом такое положение вещей выгодно Китаю, который пока еще не является сверхдержавой и не может конкурировать с США ни по объему ВВП, ни в военной сфере, ни в сфере финансовой. Однако имеющийся разрыв между США и КНР в этих областях быстро сокращается. Китайская экономика гигантскими темпами движется вперед, юань становится региональной валютой и в зонах преимущественного влияния Китая постепенно вытесняет доллар 
и йену. А если учесть то, что в 2017 г. Китай завершает комплексное перевооружение НОАК, то после этого справиться с ним будет совсем непросто. Понимают это и США. И, видимо, готовятся к будущему военному столкновению с растущей мировой державой, которая в скором времени наверняка захочет заявить о себе в новом статусе.

Вместе с тем, для принятия исторического вызова Китая Соединенным Штатам необходимо вновь набрать экономическую мощь. Это Вашингтон рассчитывает сделать за счет нового прорыва в промышленных и финансовых технологиях, что вполне реально, но требует времени, которое Штаты должны выиграть у Китая путем замедления темпов его развития. Наиболее вероятный путь достижения этой цели - перекрыть поставку в Китай углеводородов, без которых стремительно растущая китайская экономика задохнется. И именно в этом направлении США уже многое делают.

Так, гражданская война и иностранная интервенция в Ливии привела к власти проамериканский марионеточный режим, который тут же перекрыл поставки нефти в КНР. Ранее, при Каддафи, Китай получал из Ливии до $13 \%$ всей необходимой ему нефти. Еще один источник нефти, Дарфур (мятежная провинция Судана) в годы временного перемирия между крестьянами-фура и кочевникамиарабосуданцами давал Китаю до 18\% всего объема потребляемой им нефти. Но недавно ситуация в Дарфуре вновь обострилась и сейчас там с новой силой вспыхнула гражданская война. Эти обострения гражданской войны в Судане происходят не без американского участия, поддерживающего повстанцев; отряды арабосуданцев, в свою очередь, деятельно поддерживает Китай.

Еще один поставщик нефти, Иран, обеспечивает своими поставками $26 \%$ всех необходимых экономике Китая энергоносителей. И в этом плане вполне понятным становится интерес США к поставкам иранской нефти и газа в Китай. В случае перекрытия этой артерии, Китай будет испытывать явный дефицит углеводородов, а попытки компенсировать потери наращиванием поставок нефти и газа из Центральной Азии могут наткнуться на новую волну цветных революций, не раз гулявших в регионе. В этом смысле становится понятным стремление США ввести в отношении Ирана новые санкции, запретив всем импортерам, в т.ч. и Китаю, покупать иранскую нефть.

Исходя из этих предположений, напрашиваются два вероятных сценария развития ситуации с Ираном.
Первый сценарий будет разыгран США при условии того, что Китай присоединится к санкциям против Ирана и добровольно откажется от поставок иранской нефти, т.е. сам себе перекроет жизненно важную для его экономики артерию транзита углеводородов. В этом случае войны, скорее всего, не будет: Иран для США, скорее всего, не самоцель, а лишь фигура в разыгрываемой ими стратегической комбинации.

Второй сценарий вступит в силу в том случае, если Китай проигнорирует требование США и попрежнему будет закупать у Ирана нефть. Тогда Сoединенные Штаты, скорее всего, попытаются перерезать эту артерию китайской экономики силовым путем, расправившись с Ираном в ходе быстрой военной операции: Иран, при всей довольно высокой боеспособности его армии и наличии в его распоряжении еще одних, альтернативных армии, вооруженных сил - Корпуса стражей исламской революции, вряд ли сможет защитить себя от такого удара. Но главным условием для начала такой операции является надежный тыл, в котором сегодня остается только один незамиренный очаг напряженности - Сирия во главе с Башаром Асадом. Поэтому, как только с ней будет покончено, возможно, наступит черед Ирана.

Надо отметить, что перестройка экономики и финансовой системы США уже началась: контролируемый финансовый кризис позволил Вашингтону консолидировать все финансы страны в руках трех крупнейших банков, где их проще мобилизовать для достижения любой глобальной цели. Несложно проверить, что аналогичные процессы в американской истории также имели место перед двумя мировыми войнами - Первой и Второй.

\section{III. ЦВЕТНАЯ РЕВОЛЮЦИЯ В ВЕНЕСУЭЛЕ}

В настоящее время в Венесуэле разворачивается протестное движение, имеющее все признаки классической цветной революции. Это может означать, что США, реализовав сценарий цветной революции ан Украине, занялись другим союзником России - Венесуэлой.

Цветная революция в Венесуэле возможна, более того, она неизбежна. Дело в том, что авторитет и популярность Венесуэлы в латиноамериканском мире исключает грубое военное вмешательство со стороны США, как это было в Гренаде и Панаме. Поэтому в своем стремлении уничтожить завоевания Боливарианской революции и подорвать стремлении народа Венесуэлы к свободе США будут ис- 
пользовать «мягкую силу», «мягкие» технологии государственных переворотов, замаскированные под стихийные политические процессы и народные революции - так, как это было ими организовано в Тунисе, Ливии, Сирии. Особенно показателен пример Ливии, в которой цветная революция переросла гражданскую войну, а та - в интервенцию со стороны Франции и Великобритании, к которым затем пришли на помощь и сами США. Безусловно, Венесуэла - не Ливия, и здесь американцы будут применять особый сценарий, в основе которого все равно будет лежать базовая схема, общая для всех цветных революций. Скорее всего, в Венесуэле будет применена схема, повторяющая вооруженный мятеж 2013-2014 гг. в Украине, начавшийся с «евромайдана».

Те протестные движения и демонстрации, которые сегодня происходят в крупнейших городах Венесуэлы, и есть первый признак начала цветной революции. Обратите внимание на то, что протестные демонстрации происходят в крупнейших городах одновременно - следовательно, они уже сами по себе не могут рассматриваться как стихийные, поскольку речь идет о высокой степени синхронизации действий.

Второй признак - характер освещения этих протестов западными СМИ, в которой присутствуют признаки и элементы информационной войны. Есть и другие признаки, точно указывающие на не случайность и внешнюю управляемость этих протестов.

Если это - цветная революция, то поддержка оппозиционных групп извне - обязательное условие ее успешности. Организация масштабных протестов, даже выглядящих как стихийные, стоит очень дорого. Ни одн из сил внутри страны, сочувствующая мятежникам, не располагает такими финансовыми средствами. Как правило, каналы поступления финансов в страну для организации цветной революции довольно легко выявляются финансовой разведкой.

Предварительные испытания сценария цветной революции в Венесуэле были во время избирательной кампании, когда чависты фактически проиграли (или выиграли с минимальным перевесом) во всех крупных городах, но победили в провинциальной местности.

В Венесуэле используются технологии управляемого хаоса - на это также указывают все имеющиеся признаки. Технологии управляемого хаоса это технологии разрушения структур и институтов гражданского общества, которые могут противостоять мятежникам и участникам цветных революций. Они делают человеческую среду восприим- чивой к лозунгам цветных революций, поскольку технологии цветных революций разрабатывались американцами, живущими в обществе индивидуалистов и либералов, для сходных обществ и социальных формаций. В своем чистом виде технологии цветных революций буксуют ан Востоке, поскольку общества там не либеральные, а организованные по общинному, родовому или племенному принципу. Управляемый хаос разрушает общинную структуру, в результате чего множество людей оказывается лишенными общественной защиты и испытывают чувства страха и паники, заставляющие их искать спасения, сбиваясь в толпу, которую затем используют режиссеры цветных революций.

В случае Венесуэлы управляемый хаос будет обязательно задействован для того, чтобы разрушить социальное единство тех, кто получил многое от мирной революции Чавеса, и для того, чтобы ослабить остальные страны латиноамериканского мира, чтобы они не пришли Венесуэле на помощь.

\section{IV. ЦВЕТНАЯ РЕВОЛЮЦИЯ И ВООРУЖЕННЫЙ МЯТЕЖ 2013-2014 гГ. В УКРАИНЕ}

Сегодня внимание всего мира приковано к событиям в Украине. Жестокость и непримиримость борьбы, за считанные дни переросшей из отдельных столкновений хулиганов и полиции в организованный вооруженный мятеж, не может не оставаться без внимания - уличные бои в столице соседнего государства, в котором участвуют представители славянского народа, неразрывно связанного исторической судьбой с русским народом, не может не тревожить российскую общественность, правительство и руководство Российской Федерации. Украинские националисты, идущие на острите таранного удара, нанесенного действующей власти, называют эти события «революцией», хотя на самом деле это можно рассматривать исключительно как государственный переворот, вооруженный мятеж с целью захвата власти, известный в современном мире под общим названием «цветная революция». Этот вывод далеко не случаен: в событиях в Украине угадываются признаки, которые всем нам хорошо знакомы по цветным революциям на пространстве СНГ, в Грузии, в Центральной Азии, в оранжевом безумии, охватившем Украину в начале двухтысячных годов ${ }^{3}$, а также в недавних революциях Арабской Весны.

\footnotetext{
3 Кара-Мурза С. Экспорт революции: Саакашвили, Ющен-
} ко... М. 2005. 
Сравнимая украинскую (цветную) революцию 2.0 с недавними событиями на Ближнем Востоке и в Северной Африке, нельзя не отметить, что сценарий украинской революции 2014 года один в один повторяет революцию в Египте, в ходе которой был уничтожен режим X. Мубарака, а сам египетский президент смещен со своей должности и заключен в тюрьму. Совпадений слишком много:

- $\quad$ это и характер народных волнений, переросших в массовые беспорядки, которые выдавались за стихийные, но на самом деле таковыми не являлись;

- и хорошо организованное протестное движение, подкрепленное военизированными формированиями боевиков - украинских националистов, переброшенных в Киев из западных областей Украины, где они все эти годы тренировали свое боевое умение в специальных лагерях, изучая тактику сопротивления спецформированиям МВД и СБУ, а также тактику войны в городских условиях;

- это отличное оснащение боевиков, противостоящих беркуту, - шлемы-сферы, щиты, бронежилеты и штурмовые латы, наколенники и налокотники, принятые на вооружение в подразделениях армии США, несущих службу в Афганистане;

- оружие, в том числе боевое огнестрельное, для завладения которым националисты захватили несколько армейских складов;

- блокада органов власти, захват (по ленинскому принципу) стратегических и жизненно важных объектов столичной инфраструктуры;

- использование механизмов конфликтной мобилизации населения, вовлечение его в конфликт на стороне «представителей восставшего народа», разжигание ненависти к правящему режиму, широкая идеологическая обработка попавших под влияние националистов-революционеров;

- масштабная информационная война;

- грамотно организованное снабжение восставших всем необходимым для продолжения борьбы, включая спецсредства, одежду, питание, финансовые средства, идущие на оплату услуг наемников и провокаторов.

Этим сходства египетской и украинской революции не исчерпываются: и в том и в другом случае под прикрытием восставшего народа в вооруженную борьбу включаются организованные и хорошо вооруженные отряды мятежников, в Египте - исламисты, в Украине - западные националисты.
При этом общественности эта борьба, имеющая все признаки начала гражданской войны, по-прежнему преподносится как национально-освободительное движение, развернутое восставшим народом против преступного правящего режима. В этом и сеть суть любой цветной революции, ведь цветная революция - это технология организации государственного переворота в условиях искусственно созданной политической нестабильности, к которой давление на власть осуществляется в форме политического шантажа, а основной движущей силой таранного удара по власти выступает специально организованное молодежное протестное движение.

И в том, и в другом случае «восставшему народу» противостояла слабая, нерешительная и коррумпированная власть, которая боится предпринимать решительные меры, медлящая перед лицом выбора, которая мечется между недавними союзниками, которые в новых условиях стремятся от нее дистанцироваться, делает противоречивые заявления, демонстрируя свою беспомощность и дискредитируя тем самым себе едва ли не более эффективно, чем это пытаются сделать ее противники. Именно так вел себя Мубарак: он до последнего момента верил, что США придут ему на помощь и спасут его от разыгранного ими же спектакля цветной революции, надеялся, что это всего лишь воспитательная мера. Однако его надежды не оправдались, как не оправдались и ожидания Януковича, что почти европейская Украина,- это не дикий Египет, украинцы - не безграмотные арабы, все само собой рассосется.

Янукович несколько лет спустя в точности повторил поведение Мубарака: несмотря на явную угрозу со стороны разрастающегося мятежа, который начинался с пустяковых (по сути) волнений на т.н. майдане, он ничего не сделал для того, чтобы пресечь этот переворот. Вместо того, чтобы жёсткими, но справедливыми мерами навести порядок - так, как это сделал с «васильковой революцией» Лукашенко - Янукович затеял непонятную политическую игру, заигрывая то с Западом (Евросоюзом и США), то с Россией, надеясь на фоне «предназначенной ему великой роли сдерживания хаоса» в Украине получить очередные финансовые транши и от тех, и от других. Эта слабость Януковича и стала причиной того, что сначала он потерял поддержку своего электората, а затем от него отвернулись и сторонники, начавшие стремительно разбегаться или просто перебегать в лагерь противника. В этих критических условиях Янукович, отдав приказ о силовом подавлении майдана (ко- 
торый настолько фатально запоздал, что уже ничего изменить не мог, только привел к многочисленным человеческим жертвам с обеих сторон и подставил защитников государственности - силовиков, Беркут), но до конца его выполнить у него не хватило силы воли: с того момента, как мятежники подтянули на майдан незаконные вооруженные формирования националистов и стали формировать из основной массы протестующих отряды самообороны (то есть городскую милицию), подавление мятежа стало возможным только ценой большой крови. Вот на это Янукович и не решился, опасаясь при этом не столько за загубленные жизни, сколько за сохранность своих капиталов и счетов в зарубежных банках, которых его в одночасье могли лишить, признав «международным уголовным преступником». Его заигрывания с Евросоюзом также сыграли фатальную роль: ЕС сначала настаивал на том, чтобы Янукович решительно подавлял беспорядки в столице, восстанавливая законность, а когда он наконец начал это делать и пошли первые жертвы, EC тут же начал вопить о соблюдении прав человека и о геноциде режимом Януковича собственного народа, а также о необходимости срочно пойти на уступки мятежникам и вступить с ними в переговоры. Когда Янукович, следуя этой рекомендации, пошел на переговоры с мятежниками, они сочли это признанием в слабости власти и резко активизировали свои действия, вступив в фазу непримиримой вооруженной борьбы. В результате Янукович и его приспешники, вместо того, чтобы продолжать борьбу или отвечать за свои действия, просто бежали из столицы: 23 февраля 2014 года появилась информация, что Янукович тайно пытался скрыться, вылетев за рубеж на самолете без опознавательных знаков, но украинские пограничники его вернули. Таким образом, он не только оказался слабохарактерным руководителем, способным только выкачивать из страны ресурсы в доход собственного клана (то есть грабить страну, по той же схеме, как это делал Бакиев с Кыргызстаном), но и стал предателем для всех тех граждан Украины, особенно ее восточных и южных областей, которые его поддерживали, видя в нем пророссийски настроенную силу, способную сохранить целостность государства и защитить его граждан от национализма.

Различия между Египтом и Украиной на самом деле невелики: в Египте на площади Каира вышли арабы, в Киеве - украинские националисты и просто граждане, недовольные засильем донецкого клана. И в том, и в другом случае катализатором цветной революции стала «усталость от власти» - от режима Мубарака и от режима Януковича. К этому и пытаются апеллировать националисты, забывая о той очевидной аналогии, которая прослеживается между украинскими и египетскими сценариями. В аналогичных революциях в Сирии и Ливии против правящего режима выступили исламисты, с которыми эти режимы на протяжении десятилетий вели непримиримую борьбу; в Украине в составе националистов много католиков, грекокатоликов и адептов многочисленных протестантских сект, в основном носящих тоталитарный характер и проповедующих экстремизм. И в том, и в другом случае успех переворота стал возможным только благодаря слабости и бесконечным колебаниям правящего режима, первоначально чрезвычайно самоуверенного, а затем быстро павшего духом и самим своим примером давшего сигнал своим сторонникам «спасаться, кто как может». И в Египте, и в Украине цветные революции осуществлялись в несколько этапов - речь идет о революциях 2.0, к которой можно отнести события на Украине. Просто между украинскими революциями (оранжевой и нынешней) прошло 10 лет, а между египетскими - около года. В Египте после переворота к власти пришли умеренные исламисты, в Украине власть захватили крайние националисты, что примерно одно и то же.

Следуя общей логике развития мировых процессов, можно предположить, что Януковича теперь ждет участь других лидеров государств, смещенных в результате цветных революций Каддафи, например. Его сделают международным преступником, будут гоняться по всему миру, найдут где-нибудь в Африке или Латинской Америке и выдадут «оранжевым». По дороге он может пострадать «при попытке к бегству», или какой-нибудь ярый западенец случайно разрядит в него свой дробовик, не справившись с эмоциями, нахлынувшими на него на чужбине. Потому что кто знает, что обещали Януковичу западноевропейцы и американцы, подталкивая сначала на силовое подавление протестов, а затем на переговоры и фактическую капитуляцию, сопровождающуюся сдачей всех пророссийских позиций и завоеваний.

Опасность сегодняшней ситуации в Украине, прежде всего, состоит в том, что вооруженный мятеж, поднятый радикальными националистами, имеет все шансы перерасти в гражданскую войну, поскольку уже сейчас опьяневшие от вседозволенности мятежники вылавливают по всему Киеву сторонников рухнувшего режима, жестоко избива- 


\section{Международные отношения / International Relations}

ют их и, возможно, даже уничтожают (что в этих условиях вполне вероятно). Вместе с ними вылавливают сотрудников Беркута и СБУ. Отсюда недалеко и до начала «революционного террора».

Из Германии срочно прибывает Тимошенко и сразу же на майдан, руководить революцией. Не правда ли, что то напоминает? Большевики вместе с Лениным тоже прибыли из Германии, в пломбированном вагоне. Спустя сто лет сценарий повторяется даже в мелочах. Только теперь лидер новых революционеров избирает своей трибуной не броневик, а инвалидную коляску.

Цветная революция 2.0 в Киеве поставила Украину на грань гражданской войны и распада государства по геополитическими линиям напряженности, который абсолютно точно не будет проходить мирно и безболезненно: в случае распада Украину ждет югославский сценарий, война всех против всех, геноцид, террор, иностранная интервенция (как со стороны западных государств, так и со стороны Турции, посматривающих на Крым и активность крымских татар), в ходе которых число жертв будет исчисляться сотнями тысяч. Крым, в котором уже сейчас идут бои между татарами, поддерживающими Кличко, и славянским (не только русскоязычным) населением, может вообще отделиться от страны и стать либо турецким протекторатом, либо исламским квази-государством по примеру Косово. Все это сильно ударит по безопасности соседних государств, на которые может перекинуться пламя цветной революции. Последствия реализации такого сценария для России даже страшно представить. Революции Арабской Весны, прокатившись по пространству СНГ и ударив по России, могут стать началом «Христианской зимы».

В течение всего времени, пока по Северной Африке и Ближнему Востоку неслось цунами цветных революций Арабской Весны и внимание мировой общественности было приковано к трагедии Ливии и Сирии, в России не переставали спорить, куда повернет эта волна цветных революций, когда будет сметен последний бастион - режим Башара Асада. То, что новые технологии реализации цветных революций, основанные на управляемом хаосе, пройдя обкатку на арабском Востоке, этим самым Востоком не ограничатся - это было для всех более-менее очевидно. Возник вопрос: для какой же страны готовится эта мясорубка? Для Ирана, где в 2009-м году почти достигла своей цели т.н. Зеленая революция?

В качестве следующих целей цветных революций назывались государства Центральной Азии, где предыдущая модель цветных революций не смогла обеспечить стабильности марионеточных режимов, пришедших на волне цветной революции к власти; вспоминали про Беларусь, которая своей партизанщиной давно уже является сильным раздражителем для всего Запада, чем-то напоминая режим Каддафи; кое-кто упоминал Китай. Вместе с тем, волна цветных революций не продолжила форматировать мусульманский Восток, а неожиданно проявилась в Украине - непосредственно у границ России. Отсюда следует очевидный вывод: цель новой волны цветных революций - не Украина и не режим Януковича, а Россия, ее суверенитет, территориальная целостность. Потому что цветные революции - это изобретение англосаксов, североамериканцев, и только они эти технологии умеют применять на практике. Можно сказать, что цветные революции - это их фирменный почерк. Но менять Януковича на того же Кличко или Тимошенко для США нет никакого резона: все эти годы Янукович, делая вид, что он всем сердцем с Россией, на самом деле проводил полностью прозападную и проамериканскую политику, был послушным исполнителем воли Вашингтона и Брюсселя, подставляя Россию каждый раз, когда это было выгодно интересам его клана или его западным «партнерам» и «наставникам». То есть, был абсолютно с американской точки зрения - лояльным. Менять его для США не было никакого резона, также как не было необходимости смещать Мубарака, одного из самых верных и преданных союзников США в арабском мире. Поэтому американцы на начальных этапах развития цветной революции предпочитали управлять событиями, находясь в глубокой тени и вообще особо не напрягались - ведь, кто бы не победил, он все равно будет в конюшне внешней политики Соединенных Штатов. Если бы победил Янукович - цветная революция стала бы для него предупреждением и уроком, как в свое время - выступление Окруашвили против Саакашвили в Грузии. Если придет к власти Кличко или Тимошенко они первые побегут к Соединенным Штатам за внешнеполитической поддержкой и признанием, поскольку только влияние и авторитет США 4 способны сделать из обыкновенных мятежников и бандитов европолитиков, с которыми будет говорить цивилизованная Европа.

У мятежников, уничтоживших режим Януковича, после захвата власти встанет одна карди-

4 Nye Joseph S. Jr. Soft Power: The Means to Success in World Politics. New York: Public Affairs Group, 2004. 
нальная проблема: им достанется нищая страна с разрушенной и разворованной экономикой, находящаяся в перманентном кризисе, с пустым бюджетом, с огромными долгами, с коррумпированными органами власти. На преодоление этого кризиса новой власти потребуются деньги, и деньги немалые. Кроме того, необходимо будет расплатиться со сторонниками и иными «преданными борцами», которые в случае победы очень рассчитывают на свою долю бывшей госсобственности, на возможность пограбить. Да и самим лидерам не чуждо желание приумножить свое материальное положение за счет «боевых трофеев» в отданном на разграбление, фактически взятом штурмом городе и такой же стране. Где же их взять, эти деньги?

И тут на память приходит кредит в 15 млрд долларов, выделенный Украине Россией для преодоления кризисных явлений в украинской экономике. И понимание того, что кредит давался стране, а не режиму, и смена режимов не освобождает Россию от добровольно взятых на себя обязательств. Есть над чем задуматься. Похоже, финансовые затраты на организацию и проведение революции «Украинской Весны» будут покрываться за счет российского кредита, то есть за счет средств российского бюджета. В этом плане можно лишь поаплодировать американцам: они, наконец, нашли способ, как заставлять одни страны платить за проамериканские перевороты в других странах, даже если эти другие являются родственными и по культуре, и по языку, и по крови. И пожалеть славянские народы бывшего СССР, для которых именно Советский Союз («тюрьма народов», «коммунистическая империя») был единственной гарантией безопасности и мирного существования.

России, опираясь на украинский опыт, необходимо готовиться к тому, что она станет следующей в перечне мишеней англосаксонских цветных революций, обкатанных как в условиях традиционных обществ восточного типа, так и в условиях сверхцентрализованного государства, построенного по принципу «вертикали власти» и не имеющего подушки безопасности в виде гражданского общества, способного противостоять подрывным операциям организаторов цветных революций. В этом плане предпринимаемые российским руководством усилия по связыванию пассионарной активности основной массы молодежи, которая является движущей силой любой цветной революции, в форме вовлечения в различные формальные проправительственные движения («Наши», «Молодая Гвардия» и т.д.), и пресечение деятельности на территории РФ иностранных фондов-агентов, на счета которых и заканчиваются финансовые средства на организацию цветных революций, дают хотя и важный, но, в целом, все же незначительный эффект. Это - профилактика цветных революций, а не борьба с ними. Стране в современных условиях, многократно подчеркнутых вооруженным мятежом 2014 года в Украине, необходима государственная концепция по противодействию цветным революциям, как в России, так и в целом на пространстве СНГ, подкрепленная дорожной картой ее реализации. Наивно надеяться, что и на этот раз волна цветных революций обойдет Россию стороной - в политике чудес и исключений не бывает. Просто американцы долго искали подходы к России, основываясь на опыте пробной цветной революции - т.н. «революции белых ленточек» - и, наконец, такой подход нашли. Украина - это не что иное, как последняя генеральная репетиция такой революции, обкатка ее на стране со сходным менталитетом, культурой и цивилизационной идентичностью.

В сложившейся ситуации становится не совсем ясно, какое будущее ждет В. Януковича. Так, выступление В. Януковича перед журналистами 11 марта 2014 года и сделанный им ряд публичных заявлений произвели в целом неоднозначное впечатление. Вряд ли можно говорить о каком-либо резонансе - эффект от второго выступления Януковича был намного слабее, чем его первая пресс-конференция в Ростове-на-Дону. Это свидетельствует о том, что образ преследуемого главы своей страны, бежавшего в Россию от фашизма, начинает выдыхаться и скоро станет совсем неубедительным. Следовательно, надо многое успеть до того, как он окончательно выдохнется. Третий брифинг Януковича, если он будет проведен по ростовской схеме, с вероятностью в 100\% превратится в посмешище.

В выступлении Януковича прозвучало несколько важных моментов, которые получили тем самым нормативное закрепление:

- $\quad$ команда Януковича, потерявшая власть в результате переворота, наконец, осознанно заявила о себе как о единственной легитимной власти на Украине, а Янукович заявил о себе как о законном действующем президенте, не сложившем своих полномочий, и как о верховном главнокомандующем, в прямом подчинении которого остается армия, МВД, СБУ;

- цветная революция названа антиконституционным вооруженным переворотом, а его организаторы и исполнители - мятежниками; 


\section{Международные отношения / International Relations}

- $\quad$ борьбе с мятежниками придана форма борьбы с неонацизмом и неофашизмом;

- признано, что мятеж был поддержан, а возможно и инсценирован внешними силами, под которыми подразумеваются, прежде всего, США; Западу сделан упрек в поддержке неонацистов в Украине;

- Януковичем признана вина перед украинским народом «за то, что не смог сохранить стабильность».

Янукович, несмотря на все его недостатки, фигура, которой еще можно поиграть в российских интересах. Все-таки он - всенародно избранный президент Украины, единственно легитимный глава государства, вынужденный пребывать в изгнании в России, потому что в стране совершен фашистский переворот. Именно об этом он сегодня и заявил, подчеркнув свой официальный статус главы государства и верховного главнокомандующего.

Первый его статус - единственно законного главы Украины - не признается мятежниками, но сохраняет свое значение и вес в отношениях с иностранными государствами, прежде всего странами ЕС. Для них он остается легитимным президентом, по меньшей мере, до назначенной мятежниками даты выборов нового президента. Второй статус - главнокомандующего - ставит перед честными офицерами украинской армии и спецслужб непростой выбор: либо следовать присяге, подчиняясь приказам главнокомандующего, получившего эти полномочия из рук народа, либо переходить на сторону мятежников, фактически эту присягу нарушая. Многие из них, даже не симпатизируя Януковичу, все же пойдут выполнять именно его приказ - по крайней мере, до момента новых выборов президента.

В моральном плане Янукович - фигура, вышедшая в расход: он полностью себя дискредитировал и как главу государства, и как личность своим бегством из страны, единственным мотивом которого было спасти свою шкуру. Причем победа мятежников во многом кроется именно в том, что власть фактически сдала им страну, малодушно отказавшись от сопротивления в том самый момент, когда Беркут еще вел уличные бои с боевиками. Тем самым Янукович показал себя предателем народа, который сегодня пытается изображать из себя жертву обстоятельств. Если бы он был настоящим борцом, он не бежал бы в Россию, а переместился бы в Донецк или Крым и там продолжил борьбу с нацистами. Любая связь с такого рода фигурой должна быть кратковременной, поскольку Янукович уже оконча- тельно состоявшийся политический труп, никакой властью он не обладает (его не поддерживает даже его родной донецкий клан), но своей скандальной репутацией вполне еще может замазать всех, кто с ним продолжает иметь дело. Полагаю, что после того, как Янукович выполнит возлагаемые на него задачи, необходимо будет аккуратно вывести эту фигуру из медиа-поля и дистанцироваться от нее.

В формально-юридическом плане в переговорах с США и ЕС Янукович будет сохранять за собой статус всенародно избранного главы государства - по крайней мере, до начала новой внеочередной избирательной кампании, инициированной нацистами.

И этот статус делает Януковича фигурой, интересной для проведения оперативной игры с США и EC, а также - для воздействия на армию и силовые структуры Украины. Она может выстраиваться в нескольких направлениях:

- Янукович может выступить с воззванием к мировому сообществу (в ООН!) и к главам европейских государств с призывом сплотиться против фашизма и положить конец новому нацистскому мятежу. Этот призыв может содержать идею о созыве под эгидой СБ ООН международной мирной конференции (ялтинского аналога Женевы-2), которая вместе с волей украинского народа должна решить судьбу страны. В случае, если страны EC не откликнутся на эту инициативу, Янукович может попросить Россию о направлении в Украину миротворческого контингента для восстановления конституционного порядка на всей территории страны.

- Янукович может обратиться к военнослужащим Украины, честному офицерству, принимавшему присягу своему народу, а не правительству. Это обращение может носить характер не абстрактного призыва, а иметь форму приказа, который отдает действующий верховный главнокомандующий. Приказ должен вывести большую часть армии из подчинения мятежников и переподчинить их новому командированию, которое надо срочно сформировать в любом центре, противостоящем мятежникам: Донецке, Симферополе, Николаеве.

- Янукович должен предложить народу Украины программу выхода из кризиса, включающую в себя федерализацию Украины, предоставление ее регионам на выбор прав широкой автономии или права войти в состав России; объединение Украины и России в евразийскую конфедерацию на новой идеологической плат- 
форме. Этой платформой может быть идея о новой антинацистской коалиции - «третий (по историческому счету) фронт» противодействие мировой фашистской угрозе.

- Янукович должен временно оттянуть на себя негативную полемику Запада с российским руководством. Он может стать украинским аналогом Байдена, побив США их же картой.

- Наконец, после исполнения всех перечисленных выше задач, Янукович обязан легитимно уйти со сцены, передав свои полномочия преемнику строго по действующей конституции, и обеспечив запуск конституционной процедуры смены власти.

Разрешение кризиса на Украине возможно при соблюдении четырех основных условий.

Первое условие - невмешательство во внутренние дела Украины, России и славянского мира вооруженных сил стран Запада (США и их партнеров по НАТО) - в форме прямой военной интервенции по гренадскому или панамскому сценарию.

Второе условие - мирное урегулирование кризиса путем созыва мирной конференции (например, в Ялте), в которой должны принять участие все государства, обеспокоенные событиями на Украине, заинтересованные в скорейшем урегулировании кризиса мирным путем и видящие в этом единственную цель своей миротворческой миссии. Безусловно, в мирной конференции по Украине, созываемой под эгидой СБ ООН по примеру Женевы-2, должны принять участие не только Украина и Россия, но и западные страны - США, государства EC, а также новые мировые полюса, связанные с Россией различными форматами партнерских отношений: Китай, Бразилия, Индия.

Третье условие - это скорейшая федерализация Украины и превращение ее из унитарного государства в конституционную асимметричную федерацию, состоящую, как минимум, из четырех регионов - центрального округа во главе с Киевом, запада, востока, юга. Только этот шаг позволит избежать распада страны по образцу Югославии.

Четвертое условие - легитимная передача власти от Януковича любому из претендентов, который придет к власти законным путем, с помощью свободных и демократических выборов, являющихся единственным легитимным механизмом смены, обновления и воспроизводства государственной власти. Разумеется, таким кандидатом не может стать нацист или лицо, запятнавшее себя сотрудничеством с украинскими нацистами, устроившими вооруженный мятеж.

\section{VI. ПРОТИВОДЕЙСТВИЕ ЦВЕТНЫМ РЕВОЛЮЦИЯМ В РОССИИ}

Следует отметить, что операция США по переформатированию постсоветского пространства в определенной мере сегодня касается и России. Не секрет, что в организации протестного движения «За честные выборы» виден почерк режиссеров цветных революций, в котором наблюдаются все ее атрибуты - начиная от символики («белых ленточек») и заканчивая уровнем организации митингов и манифестаций, требующих вложения огромных финансовых средств. И совсем не случайно в Москву новым послом США именно в тот период был назначен Майкл Энтони Макфол, талантливый автор и режиссер «оранжевой революции» на Украине и «революции роз» в Грузии. Если сценарий «белой революции» в России финансирует Вашингтон, то делается это, в первую очередь, с одной целью: если Россия будет занята собственными проблемами, ей на определенное время будет не до Ирана. Этого времени американцам должно хватить для начала и завершения наземной операции.

В целом, сценарий «революции белых ленточек» полностью соответствует классическим сценариям цветных революций в Восточной Европе и на постсоветском пространстве, за исключением одной детали: этот сценарий - усеченный, рассчитанный скорее ан демонстрацию мощи, чем на реальный результат (смену режима). На это указывают прежде всего объемы финансирования. Которые были выделены Госдепом США на организацию цветной революции в России: один из лидеров оппозиционеров, приехавший в 2012 оду на Селигер и отрицавший какое либо участие США в событиях на Болотной площади, после того, как автор данной статьи его припер аргументами, в панике проговорился, что сумма, выделенная США на организацию «белых ленточек», была чуть больше чем сумма, потраченная на революцию роз в Грузии. Эта сумма конечно достаточна для Грузии или Украины, но ничтожно мала для России, в которой цветная революция только тогда будет иметь успех, если мятеж одновременно вспыхнет в двух десятках крупнейших городов и региональных центров. Все это указывает на то, что основная задача была - попугать российскую власть и заставить ее полностью погрузиться во внутренние проблемы, на время перестав следить за международной обстановкой.

Надобность в революции белых ленточек у США пропала после того, как стало ясно, что наземная опе- 
рация против Ирана откладывается на неопределенный срок - виной тому оказалась Сирия, с которой не удалось разобраться также быстро как с Ливией. После этого «революцию» в России по команде из Вашингтона свернули - американцы прагматично решили, что больше на нее тратить деньги не стоит.

Говоря о последствиях падения режима Кадда$ф и$, Д. Маккейн выразил мнение, что смена власти в Ливии даст сигнал и другим странам, «стремящимся к демократическим преобразованиям»: «это будет своеобразным посланием и для Башара Асада, и для Йемена, и для других диктаторов. Эхо «арабской весны» услышат во всем мире - от России и Китая до Израиля. С тех пор как молодой человек сжег себя на улице, положив начало волнениям в Тунисе, мы видим стремительно меняющийся мир», - заявил Маккейн. Таким образом, Маккейн не исключает, что следующей целью волны «финиковых революций» будет Китай и Россия 5 .

Высказывание сенатора Маккейна, несомненно, носит характер «пробного шара»; сам же он заявляет это все вполне искренне, не замечая, что им манипулируют. «Пробный шар» всегда направлен на провоцирование общественного мнения, в том числе мнения политических и военных союзников и противников США, на высказывание своего отношения к возможности такого вмешательства во внутренние дела перечисленных стран, а также на высказывание собственных оценок реальности такого вмешательства. И хотя реальный политический вес Маккейна ничтожен, а одиозность его фигуры известна всем, к этому его высказыванию все же следует относиться серьезно: такого рода прощупывание политической ситуации на предмет ее лояльности по отношению к новым целям и планам внешней экспансии США наводит на мысль, что эти планы уже разаботаны и ждут своего часа. В этом смысле высказывания Маккейна следует воспринимать как сигнал, а события в Сирии рассматривать как один из этапов реализации этого плана.

Основные принципы противодействия цветным революциям в России таковы:

1. Бороться с цветными революциями, являющимися технологиями государственных переворотов, можно только с помощью технологий такого же уровня. Отдельные меры, средства и методы здесь не принесут пользы.

\footnotetext{
5 Маккейн пророчит «арабский сценарий» России, Китаю и Израилю. // MKRU. http://www.mk.ru/politics/ news/2011/08/24/617060-makkeyn-prorochit-quotarabskiystsenariyquot-rossii-kitayu-i-izrailyu.html
}

2. Необходимо своевременно выявлять и перекрывать каналы заведения денег для организации цветных революций - цветная революция не начнется, пока в стране не будут скрыто заведены и размещены в национальных банках и фондах значительные денежные средства. Операция по их заведению в страну может начаться яза полтора-два года до реального начала революционных событий.

3. Необходимо сделать так, чтобы основная ударная сила цветных революций - пассионарная и супер подвижная молодежь в возрасте от 16 до 35 лет потеряла свою подвижность и подверженность влиянию идеологии цветных революций. Добиться этого можно только вовлекая молодежь во всевозможные молодежные общественные организации и движения, в массовый спорт, и т.д. При этом опыт такой работы с молодежью, накопленный Молодой гвардией, Наши, полезен, но он слишком односторонен и от цветной революции не спасет.

4. Цветная революция в России может начать развиваться под лозунгами регионального сепаратизма и под руководством региональных лидеров. В этом плане надо уделить внимание проблемным регионам - Кавказу, Сибири и Дальнему Востоку, где региональная политика федерального центра в 2012-2013 гг. потерпела ряд ощутимых неудач.

Ну и, наконец, в России должна быть выработана собственная модель противодействия цветным революциям, как в самой России, так и на пространстве СНГ, в ЦА и других регионах, в который Россия имеет свои национальные интересы. С цветными революциями бороться можно, поскольку их ход может быть предсказан и спрогнозирован заранее. Есть опыт Беларуси, которая справилась с «васильковой революцией» весьма изящным способом: ее спецслужбы не препятствовали протестующим, но отбирали у них палатки, продукты и все, необходимое для организации протестного лагеря. Есть еще пример цветной революции в Узбекистане, которая была подавлена силой оружия.

Существует система мер, которая помогает уменьшить риски возникновения цветных революций. Первый комплекс мер направлен на выявление и перекрытие финансовых потоков, идущих на финансирование протестного движения. Вторая группа мер направлена на вовлечение социальной базы протестного движения - молодежи в возрасте от 18 до 35 лет - в деятельность общественных организаций проправительственной направленности. 
Третья группа мер - создание в обществе «клапанов по выпуску пара», сброса напряженности, не позволяющих обществу «перегреваться» наподобие парового котла и затем выплескивать накопившуюся энергию в виде социального взрыва.
Президентом и Правительством России должна быть создана общегосударственная система противодействия цветным революциям, имеющая четкий план действий, которая затем будет востребована и другими постсоветскими странами странами.

\section{Библиография}

1. Кара-Мурза С. Экспорт революции: Саакашвили, Ющенко... М. 2005.

2. Nye Joseph S. Jr. Soft Power: The Means to Success in World Politics. New York: Public Affairs Group, 2004.

3. Hale H.E. Democracy or autocracy on the march? The colored revolutions as normal dynamics of patronal presidentialism. // Communist and Post-Communist Studies. 2006. Vol 39. №3. pp. 305-329.

4. Filiu J.-P. The Arab Revolution. Ten Lessons from the Democratic Uprising. / London: Hurst \&Co. 2011.195 p.

5. Маккейн пророчит «арабский сценарий» России, Китаю и Израилю. // MKRU. http://www.mk.ru/ politics/news/2011/08/24/617060-makkeyn-prorochit-quotarabskiy-stsenariyquot-rossii-kitayu-iizrailyu.html

6. Спиридонов В.В. Экономические причины политического конфликта на Украине // NB: Международные отношения. - 2014. - 4. - C. 45-78. DOI: 10.7256/2306-4226.2014.4.11528. URL: http://www.enotabene.ru/wi/article_11528.html

7. Гушер А.И. Политический кризис на Украине // NB: Международные отношения. - 2014. - 3. - С. 1526. DOI: 10.7256/2306-4226.2014.3.11502. URL: http://www.e-notabene.ru/wi/article_11502.html

8. Бородинов Е.Н. Причины и следствия государственного переворота на Украине // NB: Международные отношения. - 2014. - 3. - C. 36-59. DOI: 10.7256/2306-4226.2014.3.11501. URL: http://www.enotabene.ru/wi/article_11501.html

9. Филиппов В.Р. Буркина Фасо: политический кризис 2011 года // Международные отношения. - 2013. 4. - C. 424-438. DOI: 10.7256/2305-560X.2013.4.9721.

10. Курилкин А.В. Современные подходы к ведению информационных войн // Международные отношения. - 2014. - 1. - С. 75-80. DOI: 10.7256/2305-560X.2014.1.10063.

\section{References}

1. $\quad$ Kara-Murza S. Eksport revolyutsii: Saakashvili, Yushchenko... M. 2005.

2. Nye Joseph S. Jr. Soft Power: The Means to Success in World Politics. New York: Public Affairs Group, 2004.

3. Hale H.E. Democracy or autocracy on the march? The colored revolutions as normal dynamics of patronal presidentialism. // Communist and Post-Communist Studies. 2006. Vol 39. №3. pp. 305-329.

4. Filiu J.-P. The Arab Revolution. Ten Lessons from the Democratic Uprising. / London: Hurst \&Co. 2011.195 p.

5. Makkein prorochit «arabskii stsenarii» Rossii, Kitayu i Izrailyu. // MKRU. http://www.mk.ru/politics/ news/2011/08/24/617060-makkeyn-prorochit-quotarabskiy-stsenariyquot-rossii-kitayu-i-izrailyu.html

6. Spiridonov V.V. Ekonomicheskie prichiny politicheskogo konflikta na Ukraine // NB: Mezhdunarodnye otnosheniya. - 2014. - 4. - C. 45-78. DOI: 10.7256/2306-4226.2014.4.11528. URL: http://www.e-notabene. ru/wi/article_11528.html

7. Gusher A.I. Politicheskii krizis na Ukraine // NB: Mezhdunarodnye otnosheniya. - 2014. - 3. - C. 15-26. DOI: 10.7256/2306-4226.2014.3.11502. URL: http://www.e-notabene.ru/wi/article_11502.html

8. Borodinov E.N. Prichiny i sledstviya gosudarstvennogo perevorota na Ukraine // NB: Mezhdunarodnye otnosheniya. - 2014. - 3. - C. 36-59. DOI: 10.7256/2306-4226.2014.3.11501. URL: http://www.e-notabene. ru/wi/article_11501.html

9. Filippov V.R. Burkina Faso: politicheskii krizis 2011 goda // Mezhdunarodnye otnosheniya. - 2013. - 4. - C. 424-438. DOI: 10.7256/2305-560X.2013.4.9721.

10. Kurilkin A.V. Sovremennye podkhody k vedeniyu informatsionnykh voin // Mezhdunarodnye otnosheniya. 2014. - 1. - C. 75-80. DOI: 10.7256/2305-560X.2014.1.10063. 